\title{
القواعد والضوابط الأصولية في الخلاف \\ دراسة تأصيلية تطبيقية
}

Fundamental rules and controls in dispute

An applied original study

وكتوّل/ وليد بنا عليا بنأ محهم القايمليا الممريا

أستاذ أصول الفقه المشارك بقسم الفقه

كلية الحقوق - جامعة طيبة بالمدينة المنورة

\section{ملخص البحث}

هذا البحث نتاول در اسة" القو اعد و الضو ابط الأصولية في الخلاف" ويهدف إلى: جمع البح الفئ أهم القو اعد والضو ابط الأصولية في الخلاف.

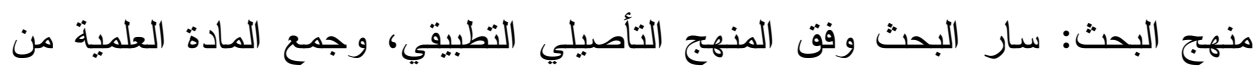

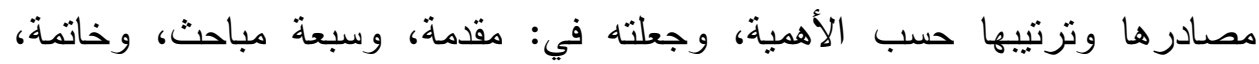
وفهارس.

وقد خلص في نهايته إلى: أنّ دراسة القو اعد والضوابط الأصولية في الخلاف

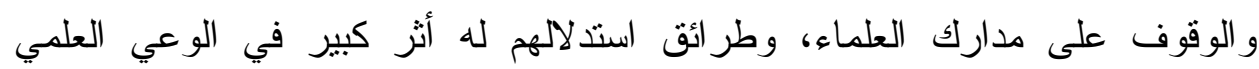

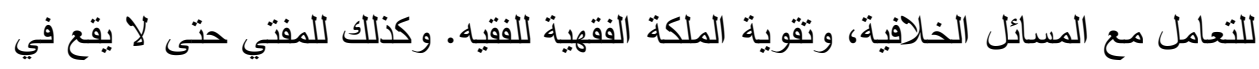

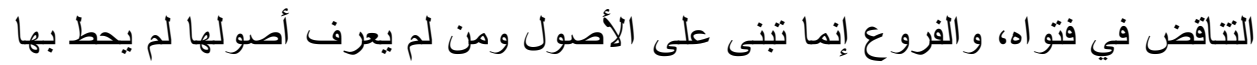
علمًا و استتباطناً.

ذكر الأصوليون عدداً من القو اعد والضو ابط الأصولية في الخلاف ومنها: "مخالفة

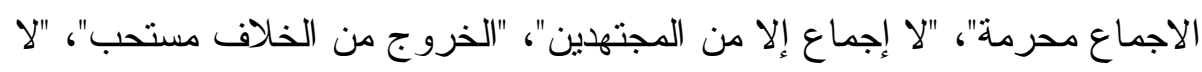

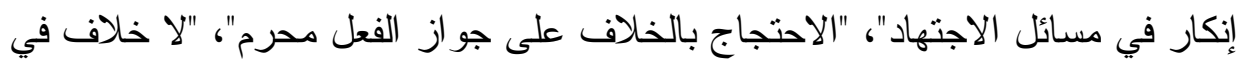

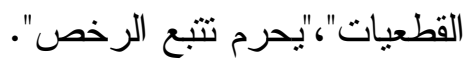

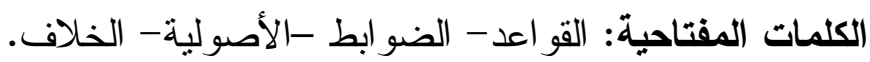




\section{Abstract}

This research deals with the study of "fundamentalist rules and regulations in the dispute" and aims to: Collect the most important fundamentalist rules and regulations in the dispute.

Research methodology: The research proceeded according to the applied methodology, and collected scientific material from its sources and arranged them according to importance, and made it into: an introduction, seven investigations, conclusion, and indexes.

In his conclusion, he concluded: The study of fundamentalist rules and regulations in the disagreement and standing on the perceptions of scholars and the methods of their reasoning has a great impact on the scientific awareness of dealing with controversial issues and strengthening the jurisprudential queen of the jurist. The same applies to the mufti so that he does not fall into contradictions in his fatwa, and the branches are rather based on the fundamentals, and whoever does not know their origins will not be aware of them and deduce.

The fundamentalists mentioned a number of fundamentalist rules and regulations in the dispute, including: "Contradicting consensus is forbidden," "There is no consensus except from the mujtahids," "leaving the dispute is desirable," "there is no denial about issues of ijtihad," "invoking disagreement over the permissibility of the act is forbidden." There is no disagreement about the pieces. "It is forbidden to follow licenses.

Key words: rules - regulations - fundamentalism - disagreement. 
بسم الله الرحمن الرحيم

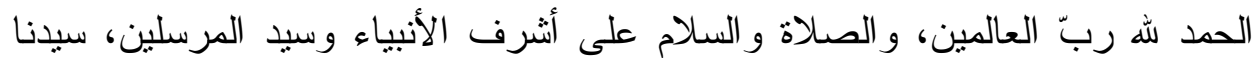
محمد و آله وصحبه أجمعين، أما بعد:

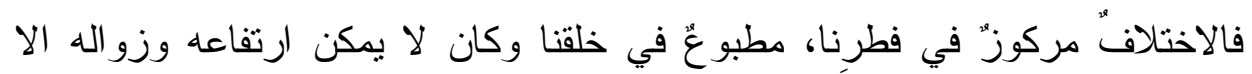

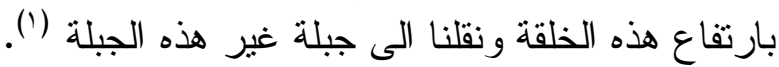

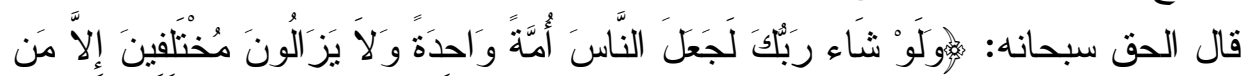

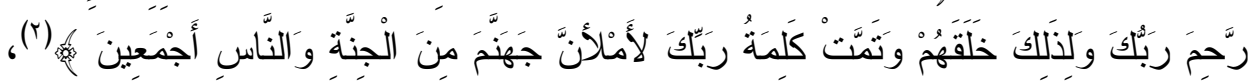

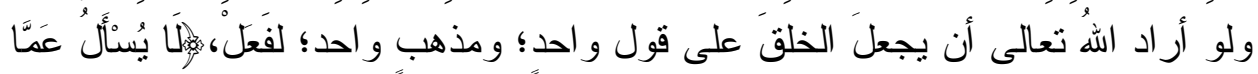

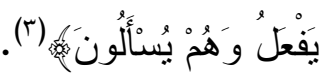
قال شيخ الإسلام ابن تيمية(ء) رحمه الله: "وقد اختلف الصحابة رضي الله عنهم في

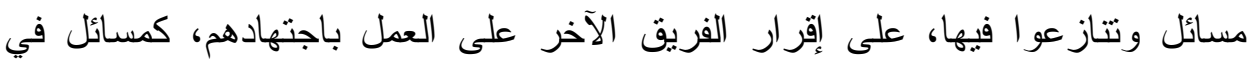

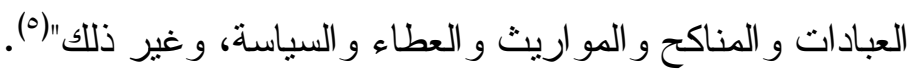

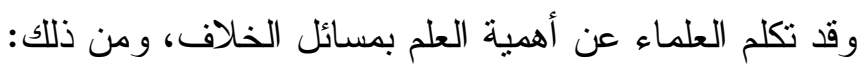

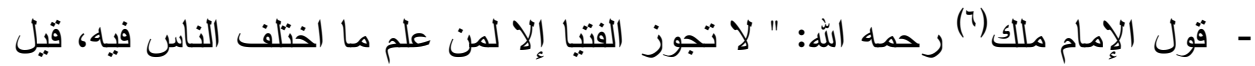
له: اختلاف أهل الرّائ؟ قال: لا، اختلاف أصحاب محمد صل الله عليه وسلم، وعلم

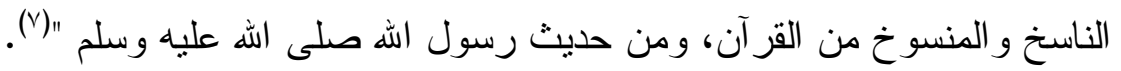

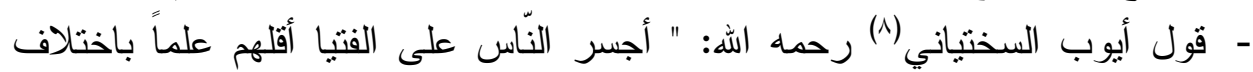

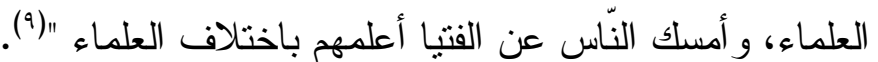

\footnotetext{
(1)

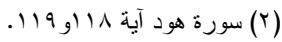

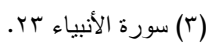

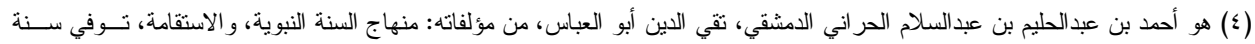

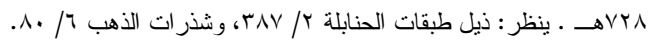

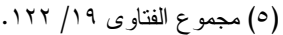

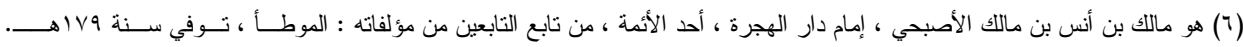

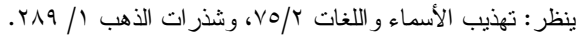

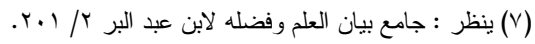

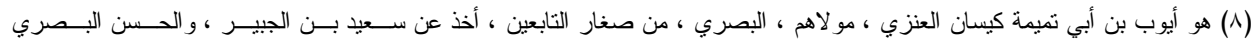

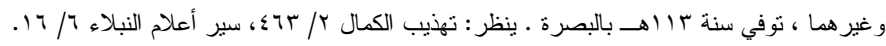

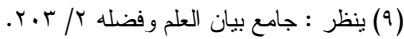


ومع وجود الخلاف بين العلماء في المسائل الأصولية، والفقهية إلا أن هنالك محاو لات

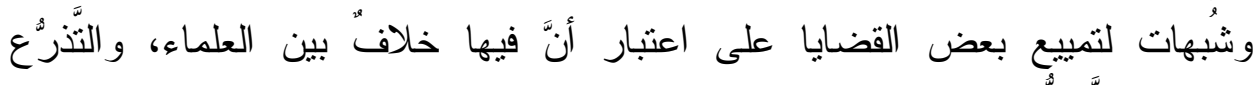

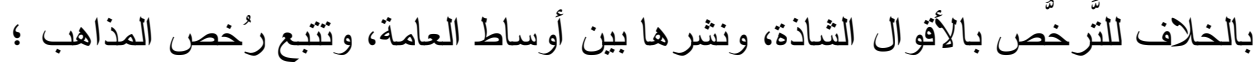

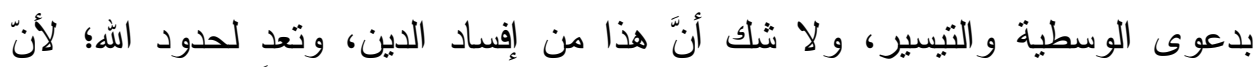

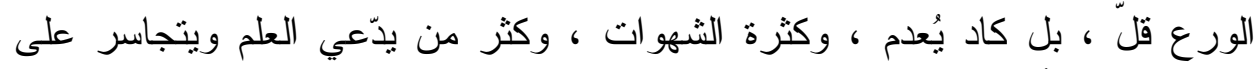

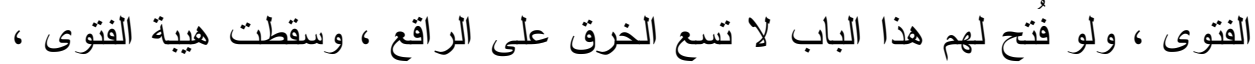

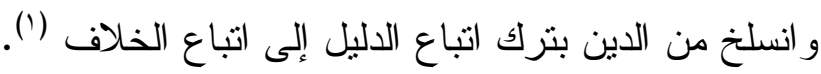

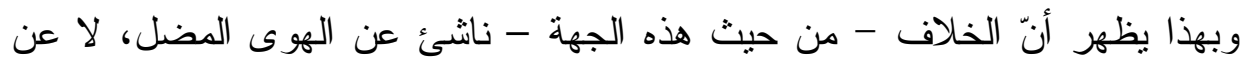

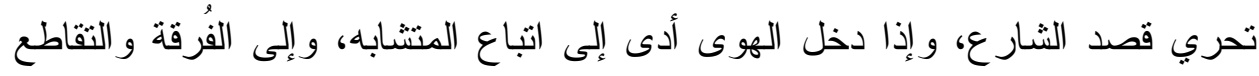
و العداوة و البخضاء؛ لاختلاف الهو اء و عدم اتفاقها.

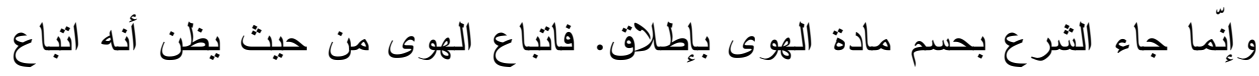

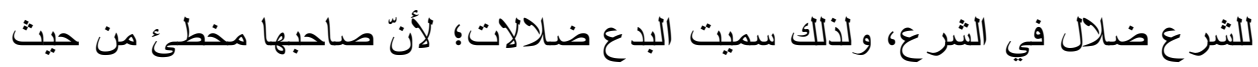
تو هم أنه مصيب، فأقو ال أهل الأهو اء غير معتد بها في الخلاف المقرر في الثرع، فلا

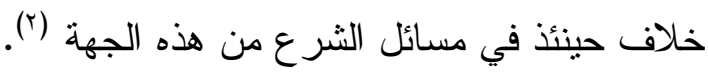
أهمية الموضوع: وتبرز أهمية معرفة القو اعد والضو ابط الأصولية من خلال أهمية القو اعد و الضوابط ذاتها في كل علم، و لاسيما علم الفقه و الأصول.

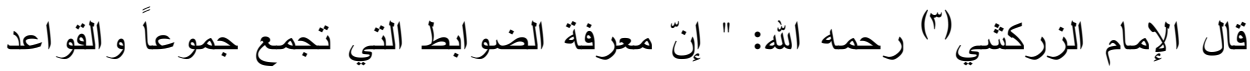

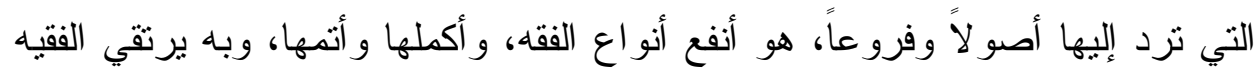

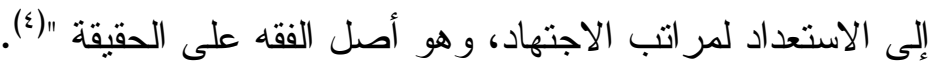

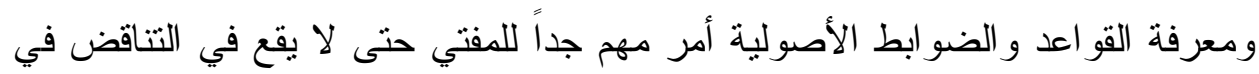
فتو اه.

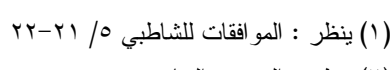
. (Y)

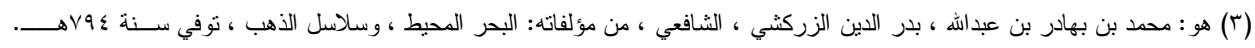

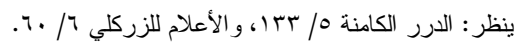

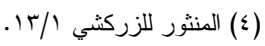


وقد أوضح شيخ الإسلام ابن تيمية رحمه الله أهمية معرفة القو اعد الكلية للمجتهد حيث

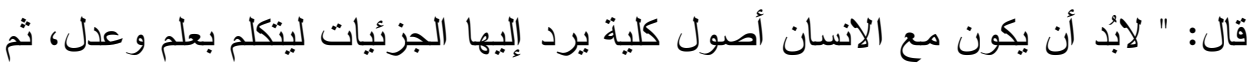
يعرف الجزئيات كيف وقعت، و إلا فيقى في كذب وجهل في الجزئيات، وجهل وظلم في الكليات فيتولد فساد عظيم ".

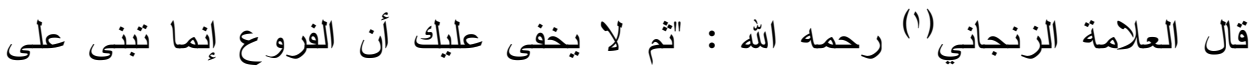
الأصول، وأن من لا يفه كيفية الاستتباط، و لا يهتدي إلى وجه الارتباط بين أحكام

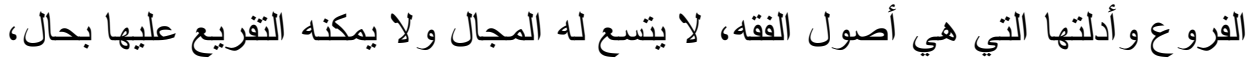

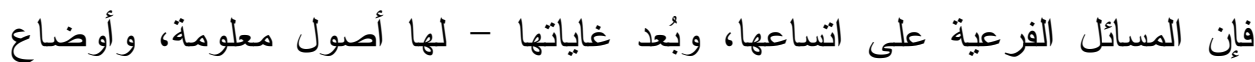

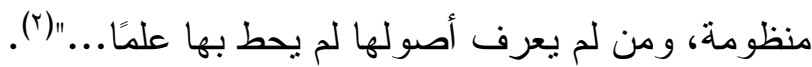
ونظراً لما تقدم أحببت أن أسهم في الكتابة عن هذا الموضوع وتحديد بعض بعض قو اعده وضوابطه الأصولية التي تحدث عنها المتخصصين من أهل الأصول، قال إمام

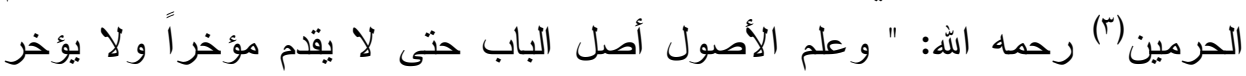

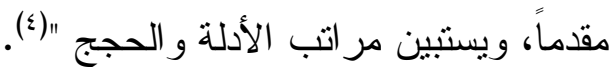
فكان عنوان هذا الموضوع " القواعد والضوابط الأصولية في الخلاف " دراسة ولة فئة

تأصيلية تطبيقية". أهداف البحث: - أبه: 1-جمع أهم القو اعد والضوابط الضد الأصولية في الخلاف.

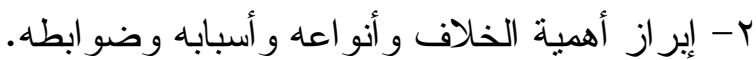

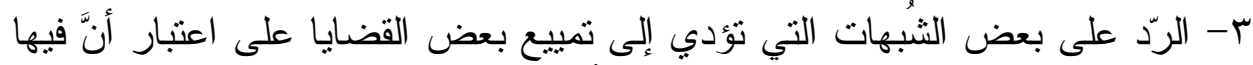

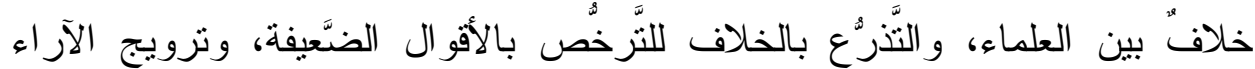
الثَّاذة ونشر ها بين أوساط الناس، وتتبع رُخص المذاهب؛ بدعوى التيسير و الوسطية.

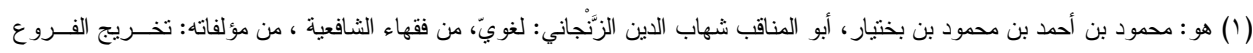

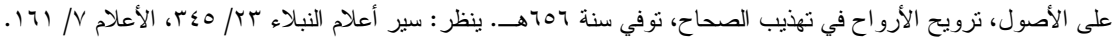

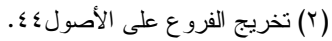

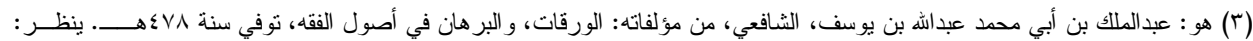

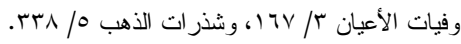

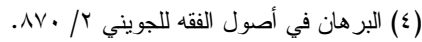


الار اسات السابقة:

جاءت هذه الدراسة في سبيل إتمام جهود السابقين، ومن أبرز الدراسات التي تكلمت

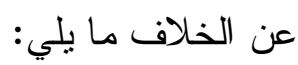
1-- أثز الاختلاف في القو اعد الأصولية في اختلاف الفقهاء د. مصطفى الخن. r-رفع الخلاف: حقيقته وطرقه د. وليد العجاجي. r- الخلاف: أنو اعه وضو ابطه وكيفية التعامل معه، د. د. حسن العصيمي. ولهي. ع -الاحتجاج بالخلاف، د. وليد بن علي الحسين.

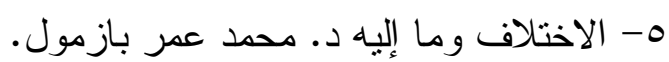

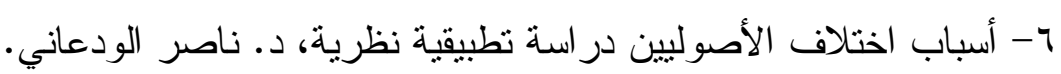

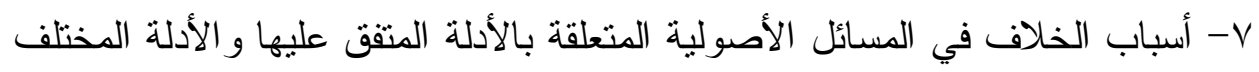
فيها، د. إسماعيل الحاج. الدر اسات السابقة تكلمت عن الخلاف و أنو اعه و أسبابه وضو ابطه و أثزه، و هذه الدراسة انفردت بجمع أهم القو اعد و الضو ابط الأصولية في الخلاف تأصبيلاً وتطبيقاً.

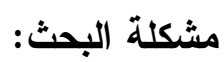
تكمن مشكلة الدّر اسة في حقيقة القو اعد و الضو ابط الأصولية في الخلاف، و الذي كان لابد فيه من الإجابة عن الأسئلة التالية:

$$
\text { وهي كما يلي: }
$$

r-وما هي أهيته في در اسة المسائل الأصولية؟ ب-وما هي أنواع الخلاف و أسبابه؟

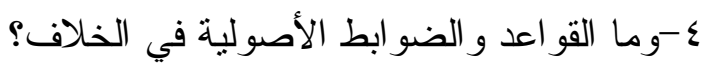
فتأتي هذه الدر اسة للإجابة عن هذه الأسئلة. منهج البحث: سلكت في هذا البحث المنهج التالي: ا-بار البحث وفق المنهج التأصيلي التطبيقي. Y-جمع المادة العلمية من مصادر ها وترتيبها حسب الأهمية. r-سرت وفْق المنهج العلمي: من حيث التوثيق و العزو و الإحالة. 


$$
\text { ع-عزوت الآيات إلى سور ها، مع ذكر رقم الآية وأسم السورة. }
$$

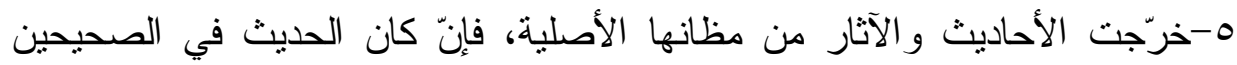
اكتفيت بذلك و إلا خرجته من مصادره المعتمدة.

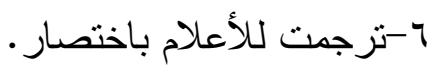
V-ذيلت البحث بالفهارس المطلوبة فهرس المر اجع و المصادر ، وفهرس الموضو عات. خطة البحث: في مقدمة، وسبعة مباحث، وخاتمة، وفهارس. المبحث الأول: التعريف بالقو اعد و الضو ابط الأصولية. المبحث الثاني: تعريف الخلاف في اللغة و الاصطلاح. المبحث الثالث: أهمية الخلاف في در اسة المسائل الأصولية و الفقهية. المبحث الر ابع: أنواع الخلاف. المعند. المبحث الخامس: أسباب الخلاف بين العلماء. المبحث السادس: أسباب عدم الاعتداد بالخلاف. المبحث السابع: القو اعد والضو ابط الأصولية في الخلاف. الخاتمة: وفيها أهم النتائج و التوصيات. الفهارس: فهرس المصادر و المر اجع، وفهرس الموضوضات وضو عات. 


\section{المبحث الأول: التعريف بالقواعد والضوابط الأصولية.

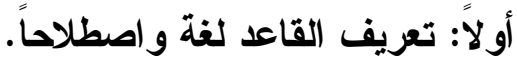

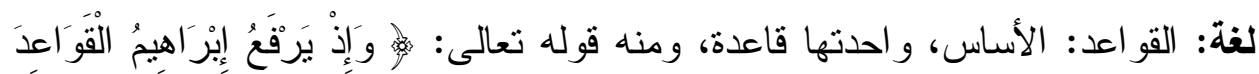

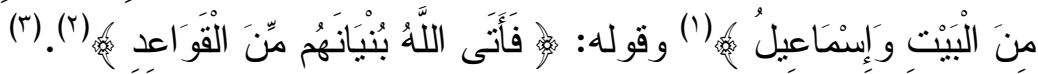
واصطلاحاً: اختلفت عبار ات العلماء في تعريف القاعدة، وكلها تدور حول معان مثقاربة ومن هذه التعاريف: اقضيَّة كليَّة من حيثُ اشتمالها بالقوَّة على أحكام جزئيات

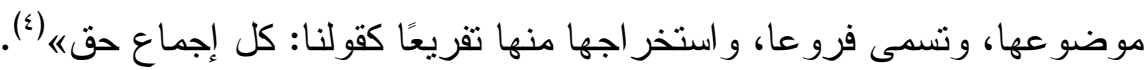

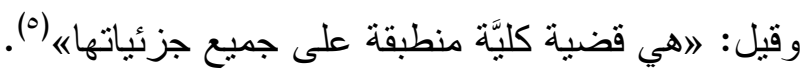
ثانياً: الضابط في اللغة والاصطلاح.

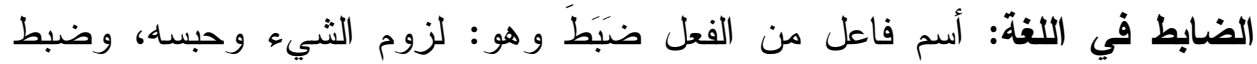

الثيء: حفظه بالحزم، و الرجل ضابط، أب: حازم. و الضبط إحكام الشيء و إتقانه (؟).

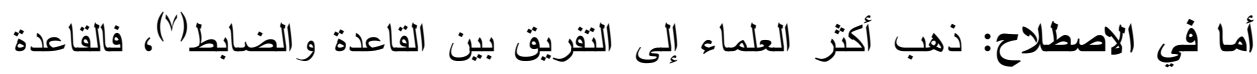
تجمع فروعا من أبو اب شتى، و الضابط يجمعها من باب و احد.

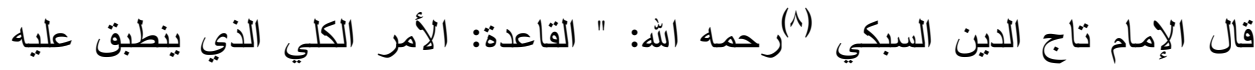
جزئيات كثيرة يفهم أحكامها. ومنها ما لا يختص بباب، كقولنا: اليقين لا يرفع الثلك، ومنها ما يختص كقولنا: كل

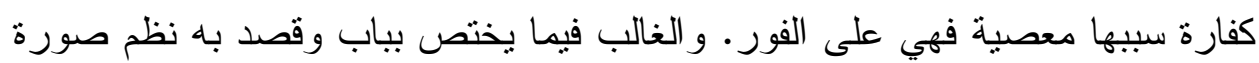

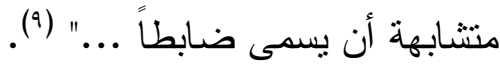

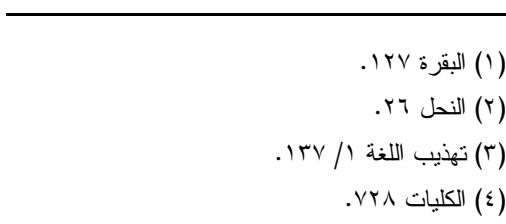

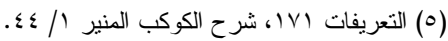

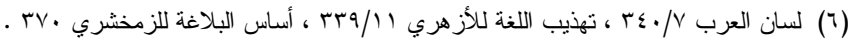

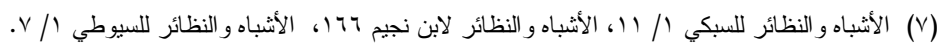

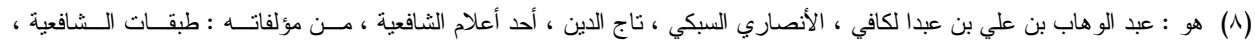

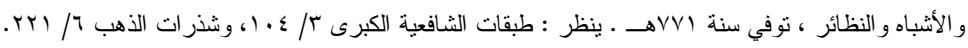
(9) الأشباه و النظائر للسبكي 111/ 
وذهب بعض أهل العلم إلى عدم التفريق، أي: أنهما متر ادفان بمعنى واحد(')، فعرفهما

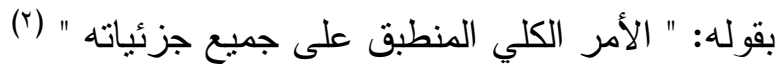

ومنهم من عرف الضابط " بالقاعدة الكلية الناظمة للقضايا المتشابهة و المتداخلة "(").

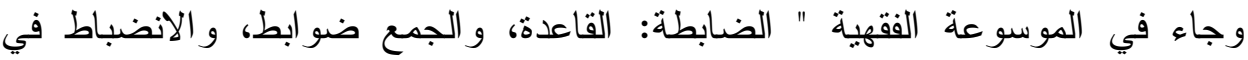
الاصطلاح: الاندراج والانتظام تحت ضابط أي: حكم كلي، وبه يكون الثيء

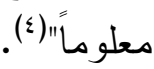
و الذي يظهر أن الغالب فيما يختص بباب وقُصد به نظم صورة منتشابهة أن يُسمى

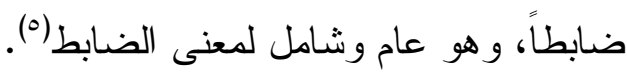

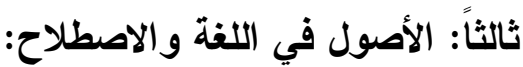
الأصول لغة: جمع أصل، وله معان متعددة في اللغة أقربها معنيان:

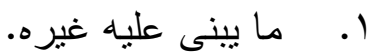

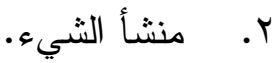

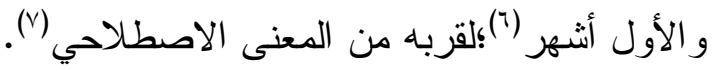

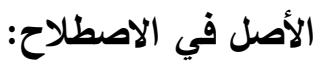
له اله معان متعددة منها: ا. الاليل: كقولهم، أصل هذه المسألة الكتاب و السنة، ومنه أيضا أصول الفقه، أي

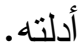
r . الرجحان: كقولهم: الأصل في الكلام الحقيقة، أب الراجح عند السامع و المتبادر إلى ذهنه هو الحقيقة لا المجاز • المعن

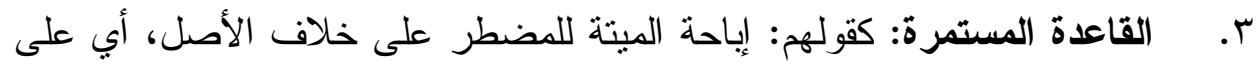
خلاف القاعدة المستمرة.

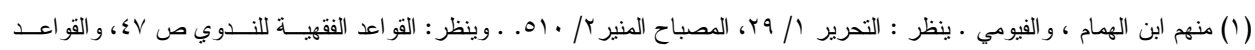

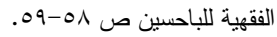

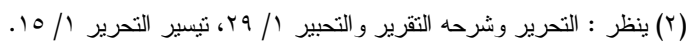

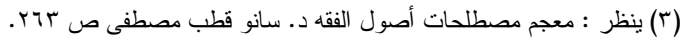

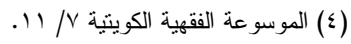

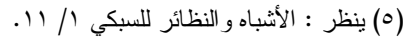

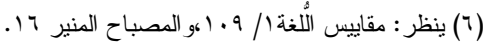

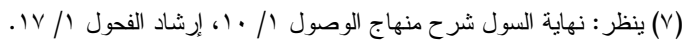


ع. الصورة التي قيس عليها: وهي أحد أركان القياس، إذ لا بد فيه من أصل يقاس عليه، وفر ع يلحقه حكم الأصل. و أقرب هذه المعاني الأول وهو المر اد في علم أصول الصول الفقه ('). والفقه في اللغة: العلم بالثيء و الفهم له لهان.

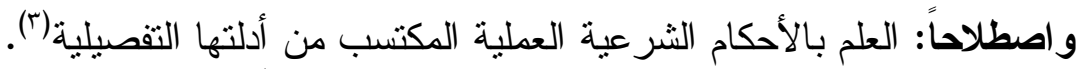

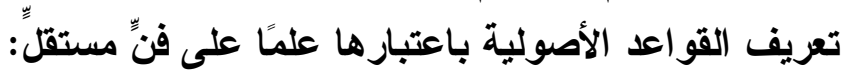

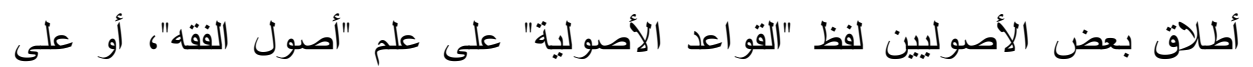

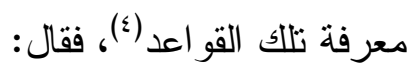
1- " أصول الفقه: العلم بالقواعد التي يُتوصل بهاعل إلى استتباط الأحكام الشّرعية الفرعية عن أدلتها التقصيلية "(0).

r- " أصول الفقه: القو اعد التي يتوصل بها إلى استتباط الفقه"(آ). r- أصول الفقه:"القو اعد التي يتوصل بها إلى استتباط الأحكام الثرعية من الأدلة"(V).

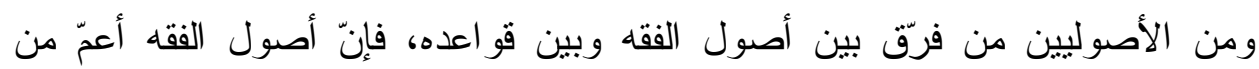

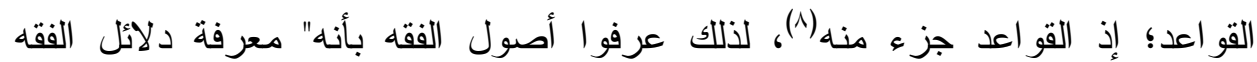

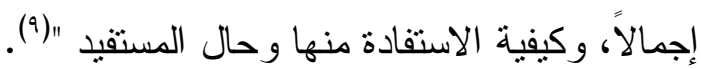
ونجد بعض المعاصرين قد حاول وضع تصوراً ومفهوماً للقو اعد الأصولية ومن هذه الأه ونهال

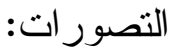

ا - دلالة يهتدي بها المجتهد للتوصل إلى استخر اج الأحكام الفقهية، فهي آلته التي

يستعطلها لاستفادة تلك الأحكام الققهية(·'). 
r- هي:" تللك الأسس و الخطط، و المناهج التي يضعها المجتهد نَصب عينيه عند البدء

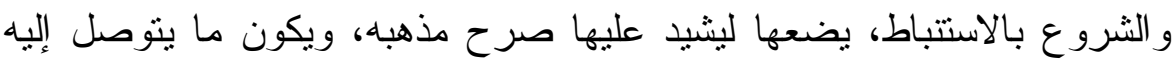

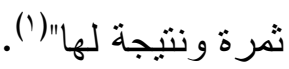

وكل هذه التصور ات و المعاني قريبة من المدلول، لكن من صفات القاعدة أن تكون

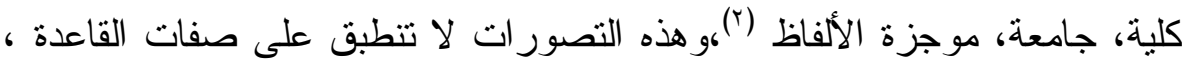
و أقرب تعريف في نظري و العلم عند الله هو :" قضية كلية يتوصل بها إلى استتباط

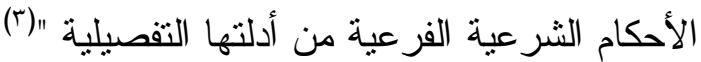
رابعاً: تعريف الضابط الأصولي باعتباره مصطلحاً علميا.

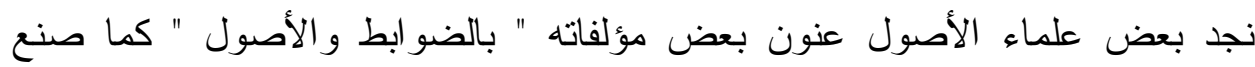

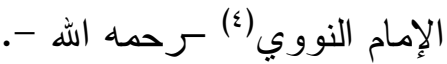
و المتتبع لإطلاقات الضابط في كتب الأصول نجدهم يطلقون الضابط على عدد من المعاني منها (م): 1- اطلاق الضابط على الثرط، كقولهم " الضابط: أن كل قراءة اثتهرت بعد صحة إسنادها وموافقتها خطة المصحف، ولم ينكر من جهة العربية، فهي القر اعة

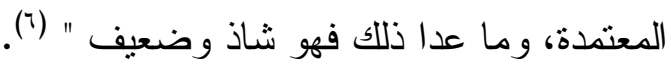

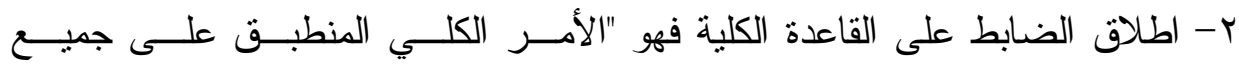

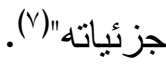
ب- اطلاق الضابط على "المعنى الاصطلاحي الاصولي"، كقولهم: " فضابط المرسل

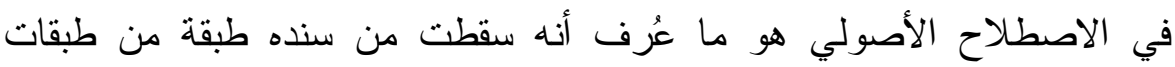


السند"(')، وقولهم: " وضابطه -الكلي -عند أرباب المعقول ما لا يمنع تصوره من

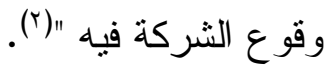

ع - اطلاق الضابط على معناه اللغوي وهو : الحبس و الحصر و التمييز (َ).

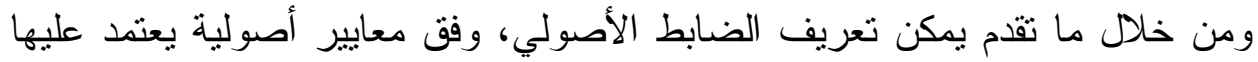
في استتباط الأحكام الثرعية سو اء جمع فروعاً من باب و احد، أو أبو اب مختلفة، فيقال " قضية كلية أصولية خاصة بباب واحد - أو أبواب متعددة-منطبقة على جميع

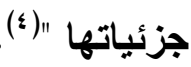

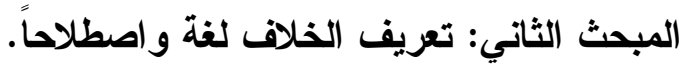

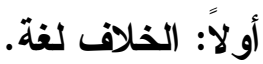

هو مصدر خالف، كما أن الاختلاف مصدر اختلف، والخلاف هو : المضادة، وقد خالفه مخالفة وخلافاً، وتخالف الأمران واختلفا، لم يتققا، وكل ما لم يتساوَ فقد تخالف هول و اختلف.

فمعنى الخلاف والاختلاف هو المضادة و المعارضة وعدم المماتلة (0). ثانياً: الخلاف في الاصطلاح.

هو : منازعة تجري بين المتعارضين؛ لتحقيق حق أو لإبطال باطل(آ).

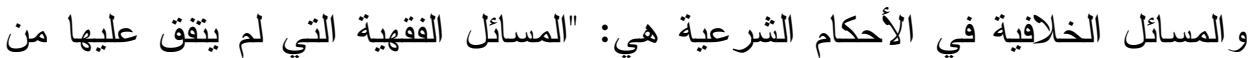
يعتد بخلافه من العلماء"(v) فكل و اقعة تباينت آراء الفقهاء أو الأصوليين في حكمها لظهور دليل أو اعتبار تعليل لتحقيق حق أو لإبطال باطل تُعد من المسائل الخلافية (^).

(1) بنظر : مذكرة أصول الفقه للعلامة الثنقيطي 10.

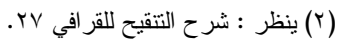

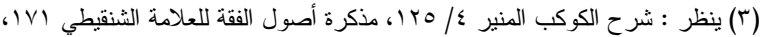

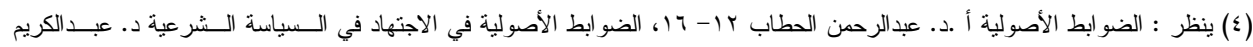
الثقاقي rV-rV.

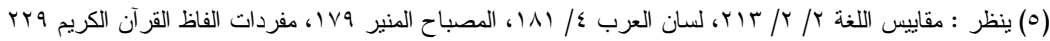

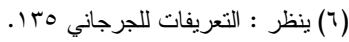
(V)

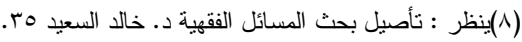


المبحث الثالث: أهمية الخلاف في دراسة المسائل الفقهية والأصولية.

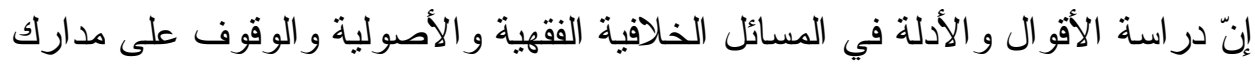

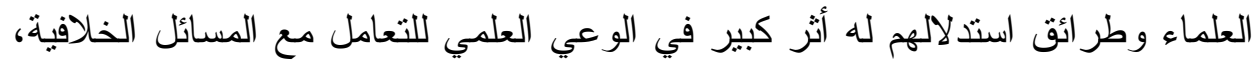

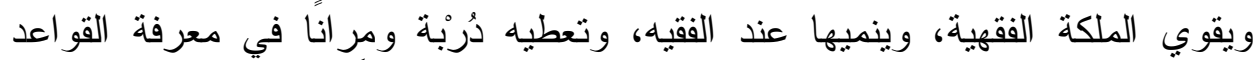
و الأصول، وكيفية رد الفروع إليها ردًا صحيحًا ومحكمًا (1).

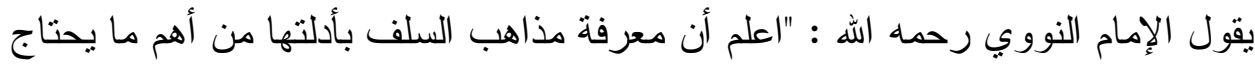

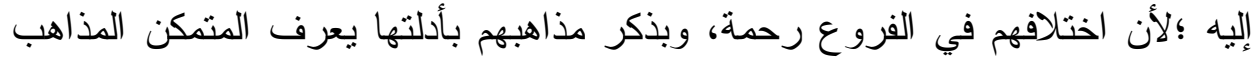

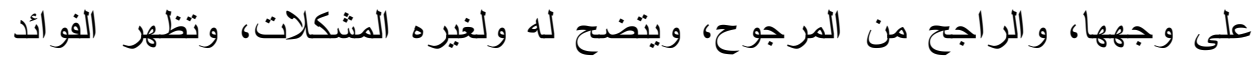

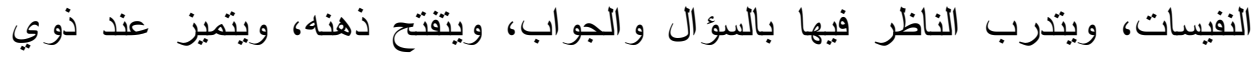

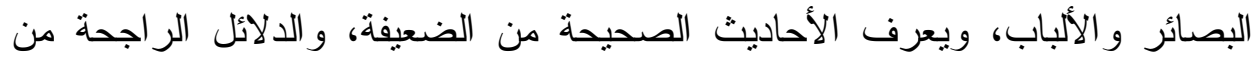

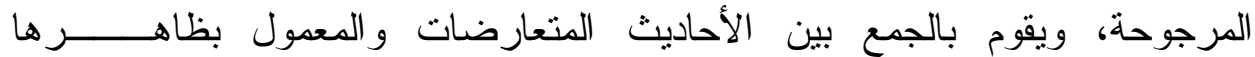

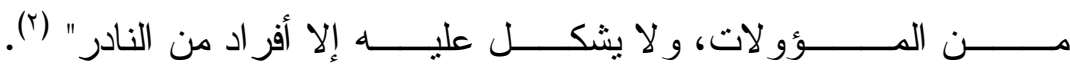

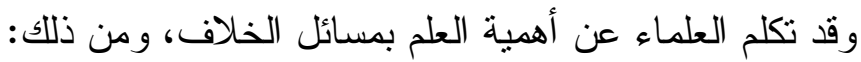

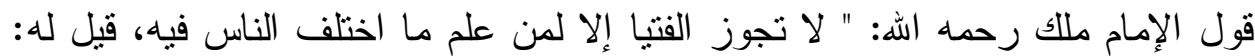
اختلاف أهل الرّأي؟ قال: لا، اختلاف أصحاب محمد صل اله عليه وسلم، وعلم الناسخ

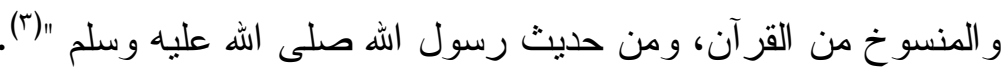

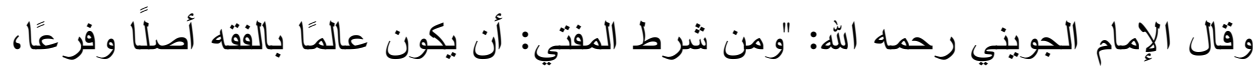

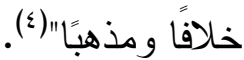

قال الإمام الثاطبي (0)رحمه الهة:" ولذلك جعل الناس العلم معرفة الاختلاف" (().

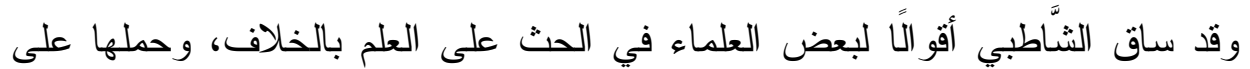
معرفة مو اقعها ومو اضعها، ومن ذللك :

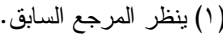

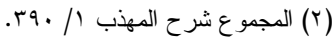

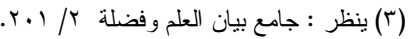

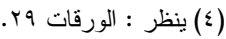

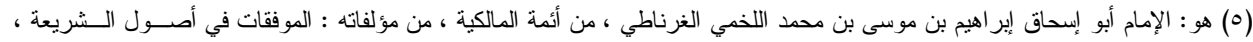

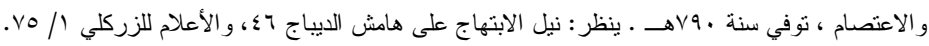




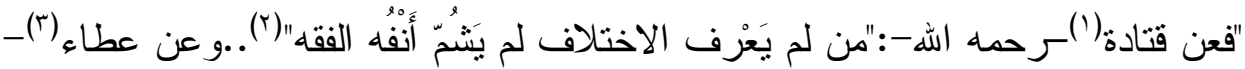

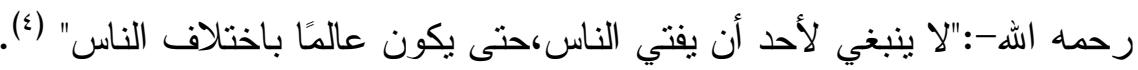

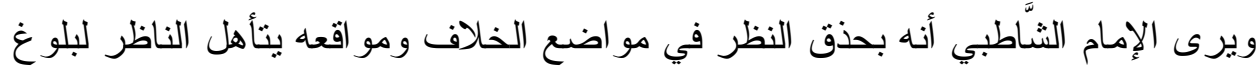

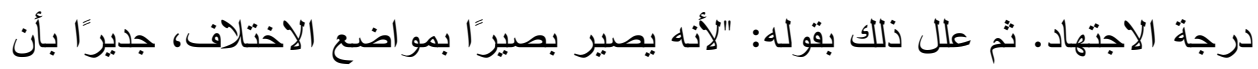
يتبين له الحق في كل نازلة تعرض لها لهاده

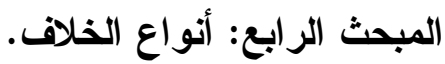
ينقسم الخلاف إلى أقسام متعددة بعدة اعتبار ات:

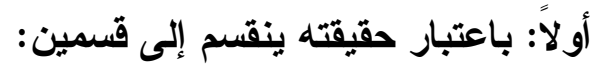

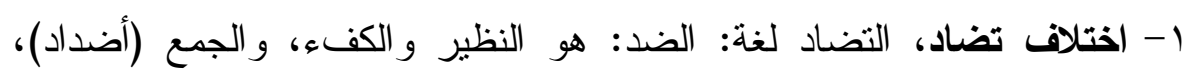
وضد الثيء: خلافه وضادة الثيء مضاده إذا باينه مخالفة. و المتضادان

اللذان لا يجتمعان كالليل و النهار (o).

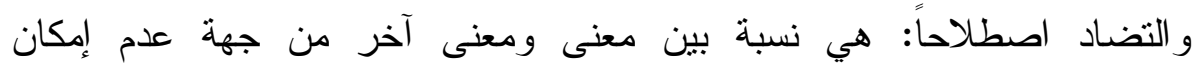

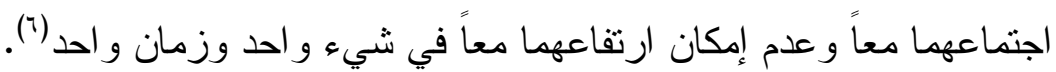

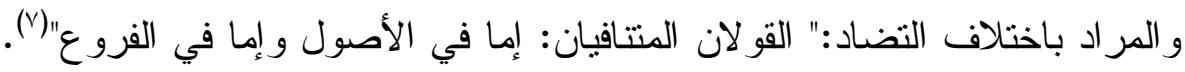

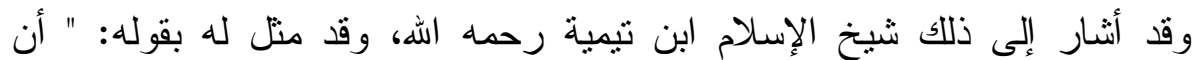

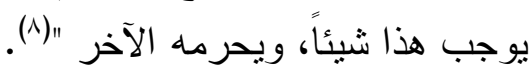
و النصوص الشرعية لا يقع فيها التضاد و التتافي بينهما في نفس الأنر الأر .

(1) هو : هو أبو الخطاب قتادة بن دعامة بن قتادة بن عزيز ، وقيل قتنادة بن دعامة بن عكابة السدوسي البصري، و السدوسي هي إحدى قبائسل

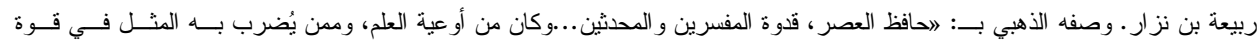

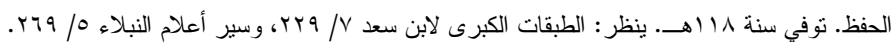

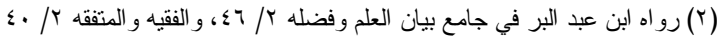

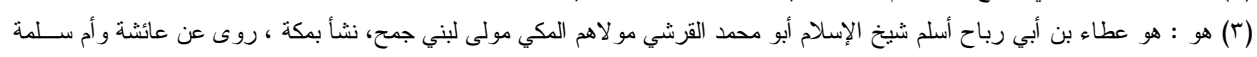

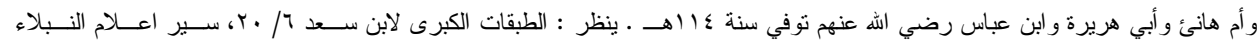


قال إمام الحرمين الجويني رحمه الهه في اختلاف التضاد: "يستحيل أن يكون الثيء الثي الثياء

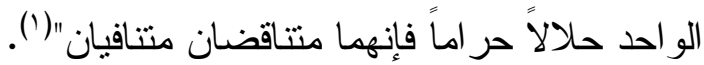

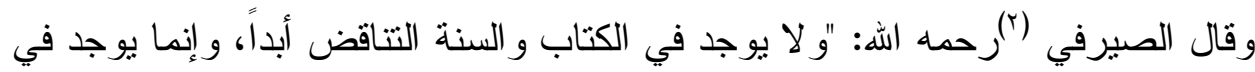

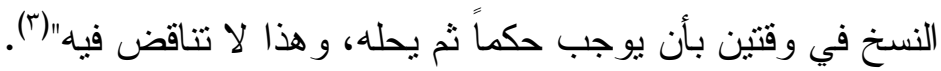

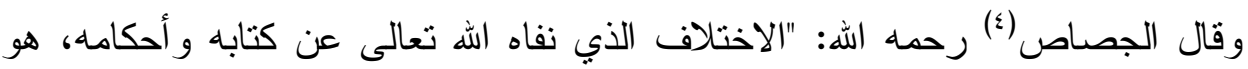
اختلاف التضاد و التنافي، وذللك غير موجود في أحكام الله تعالى"(0).

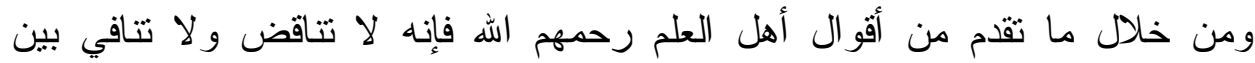
نصوص الوحبين، و إذا وجد فإنه يكون في نظر المجتهدين وفهمه.

\section{r - اختلاف التنوع.}

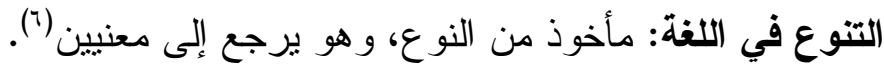

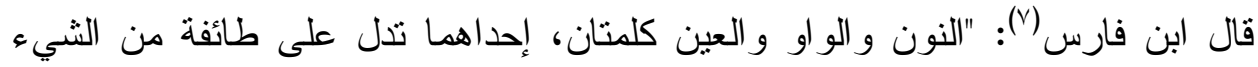

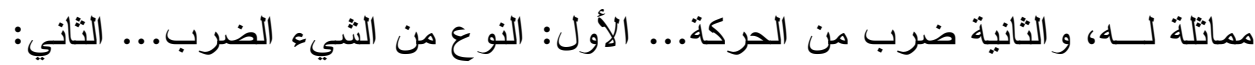
ناع الغصن ينوع إذا تمايل"(^). و التنوع اصطلاحاً: كون الثيء متعدداً ومتفقاً في الحقيقة.

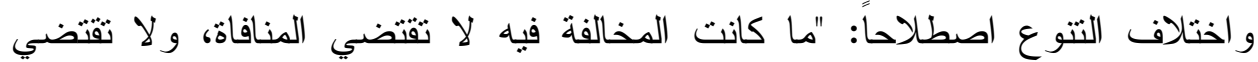

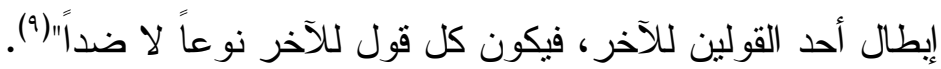
وقيل: "هو ما لا يكون فيه أحد الأقوال مناقضاً للأقو ال الأخرى، بل فل فل كل الأقوال

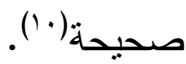

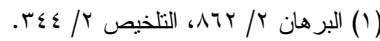

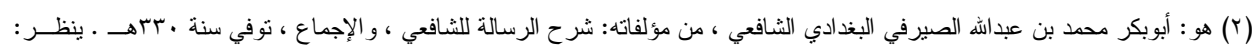

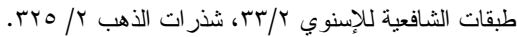

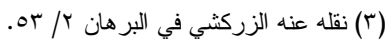

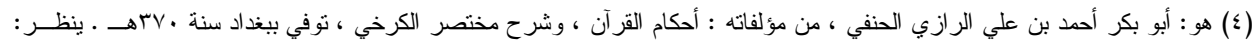

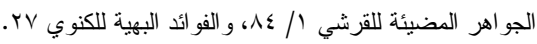

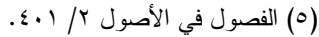

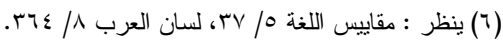

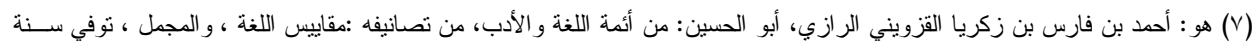

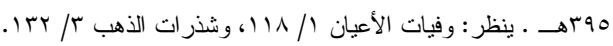

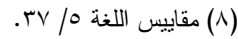

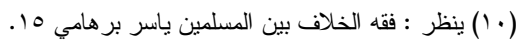


قال شيخ الإسلام ابن تيمية رحمه الله: " واختلاف التنوع على وجوه منه: ما يكون كل و احد من القولين أو الفعلين حقا مشروعا، كما في القراءات التي لتي اختلف فيها الصحابة... ومتلكه اختلاف الأنواع في صفة الأذان، و الإقامة، و الاستفتاح، و التشهدات، وصلاة الخوف.... و إن كان قد يقال: إن بعض أنوانه اعه أفضل..... ومنه: ما يكون كل من القولين هو في معنى قول الآخر؛ لكن العبارتان مختلفتان، كما قد يختلف كثير من الناس في ألفاظ الحدود وصيغ الأدلة، والتعبير عن المسميات،

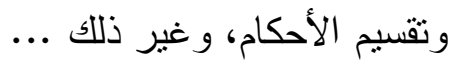
ومنه: ما يكون المعنيان غيرين لكن لا يتتافيان؛ فهذا قول صحيح، وهذا قول صحيح

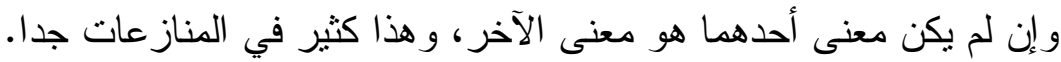

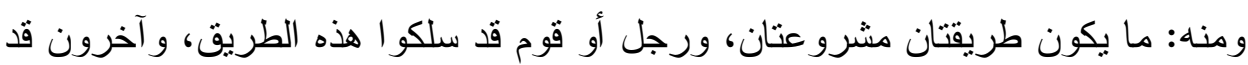
سلكو ا الأخرى، وكلاهما حسن في الدين..." (1").

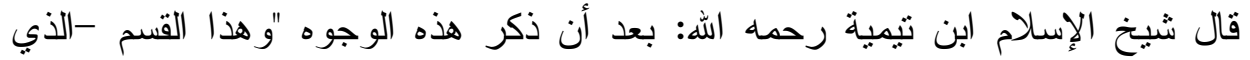

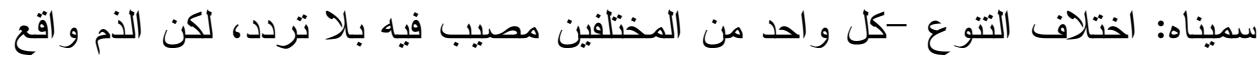
على من بغى على الآخر فيه، وقد دل القرآن على حمد كل واحد من الطائفتين في منل

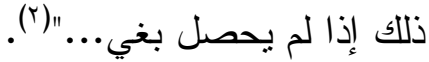

القسم الثاني: ينقسم الخلاف باعتبار القبول و الرد إلى نوعين، هما:

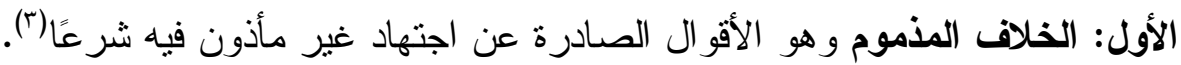

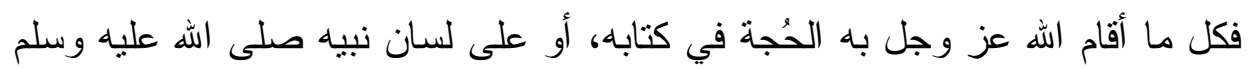

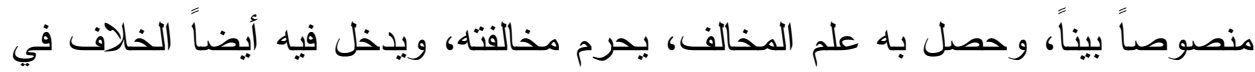

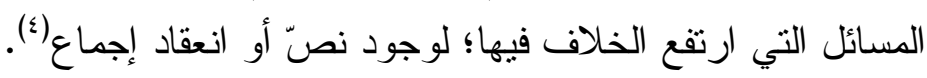

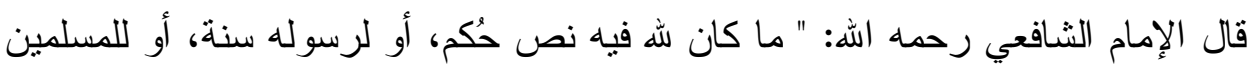

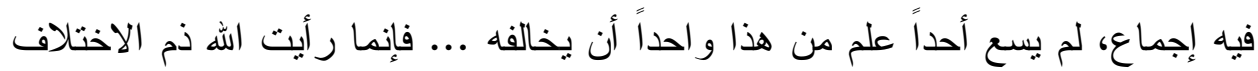

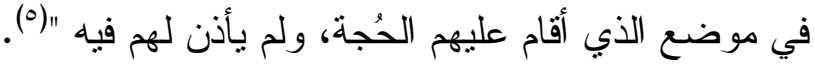

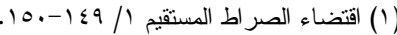

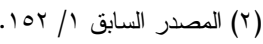

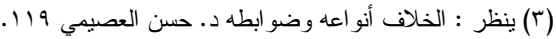

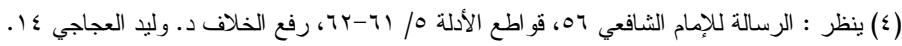

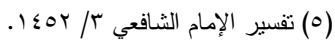


ويقول أيضاً: " قال: فإني أجد أهل العلم قديماً وحديثاً مختلفين في بعض أمورهم، فهل

بسعهم ذلك؟

قال: فقلت له: الاختلاف من وجهين:

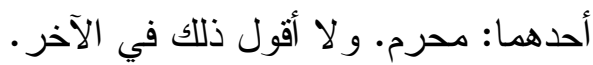

قال: فما الاختلاف المحرم؟ ملاء قلت: كل ما أقام الهه به الحجة في كتابه، أو على لسان نبان نبيه، منصوصـاً بيِّناً: لم يحل الاختلاف فيه، لمن علمه.

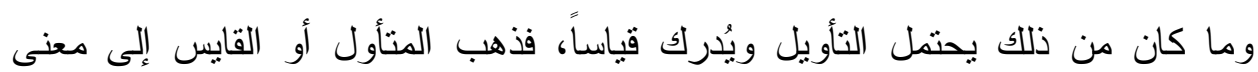

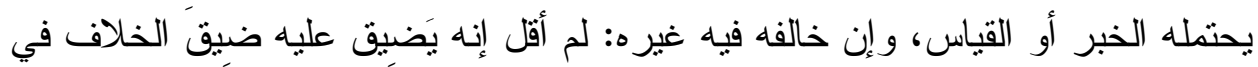

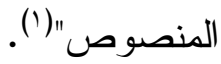
ومن صور الاختلاف المذموم:

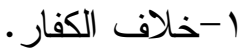
r-خلاف أهل الأهو اءه و البدع. r-الخلاف الواقع في المسائل التي لا مساغ للاجتهاد فيها، أو أن يكون الناظر في المسائل ليس أهلاً للاجتهاد. ع-الخلاف في المسائل التي فيها مجال للاجتهاد ولكن صاحَبَ ذلك الخلاف بغي أو الو

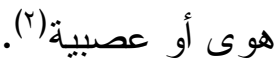
الثاني: الخلاف السائغ هو : الأقو ال الصادرة عن اجتهاد مأذون فيه شرعًامَّا".

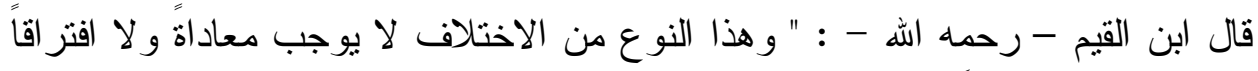
في الكلمة ولا تبديداً للشمل ؛ فإن الصحابة رضي الله عنهم اختلفو الفي مسائل كثيرة

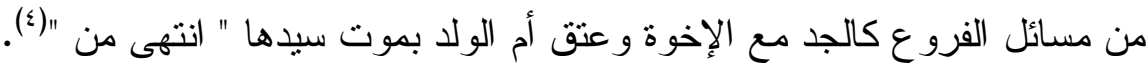

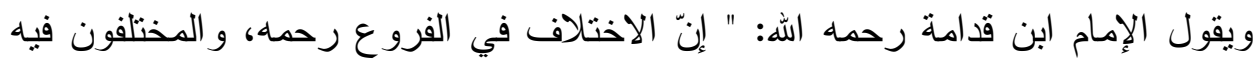

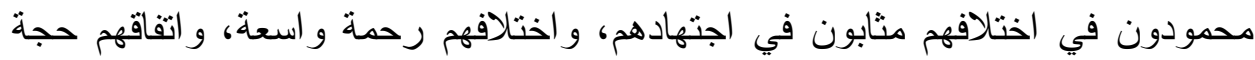
قاطعة "(0) 


$$
\text { وله ضو ابط ومن أهمها: }
$$

1- بون الناظر في تلأك المسألة مجتهدًا.

r- أن يبذل المجتهـ وسعه حين النظر في المسألة. r- كون المسألة المختلف فيها من المسائل التي للاجتهاد فيها مجال؛ كأن تكون من فن

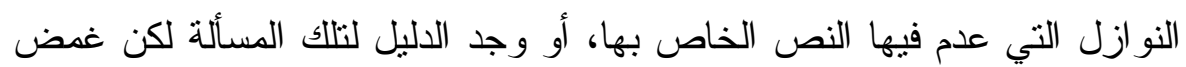
وجه الدلالة ودق؛، أو تعارض في تلك المسألة دليلان على ما هو معروف في باب لهاب

$$
\text { التعارض و التز جيح. }
$$

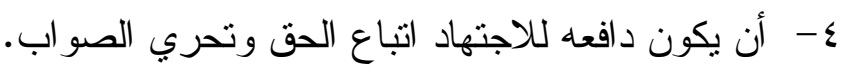

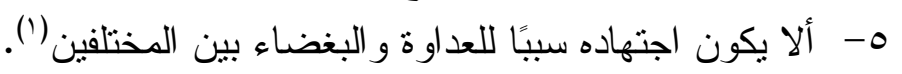

القسم الثالث: وينقسم الخلاف باعتبار نتائجه وثماره إلى قسمين:

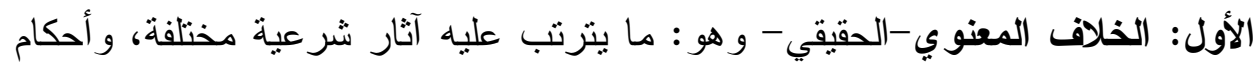

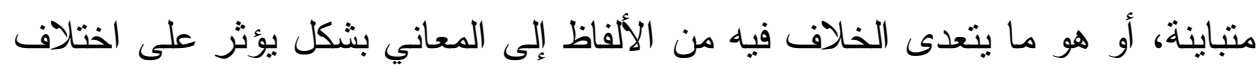

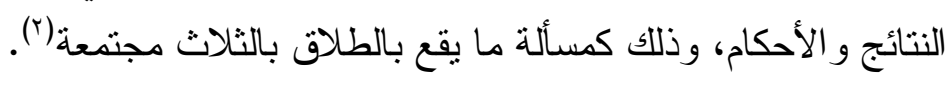
الثاني: الخلاف اللفظي: هو ما يرجع فيه الخلاف إلى التسمية و الاصطلاح الفقهي وهو

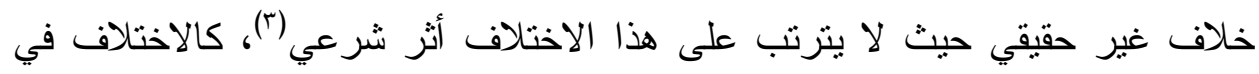

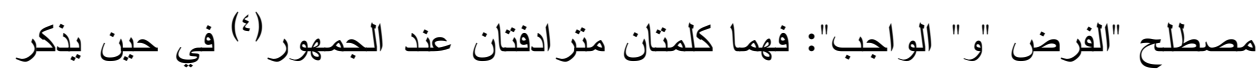

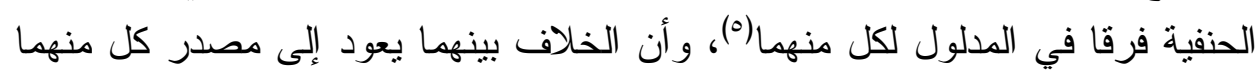

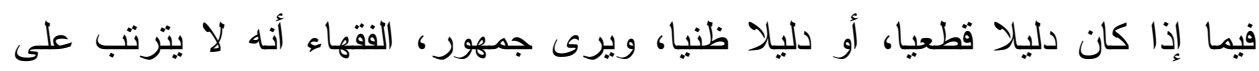

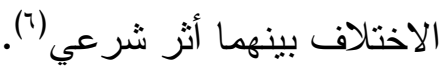
المبحث الخامس: أسباب الخلاف بين العلماء.

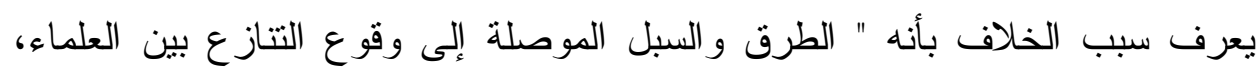
و التي تكون مثنار التتاز ع بين العلماء "(V).

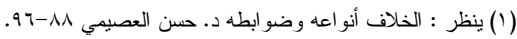

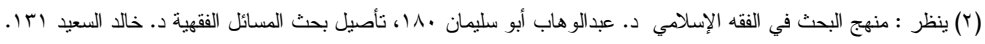

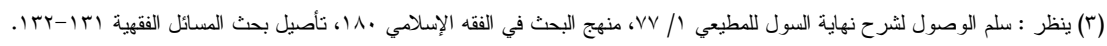

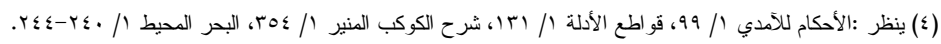

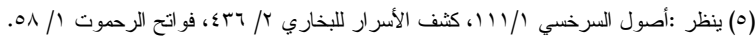

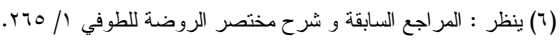

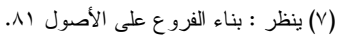


أو بعبارة أدق هو : " ما يعرف به مثار التناز ع في المسائل الفقهية أو الأصولية، ومأخذ

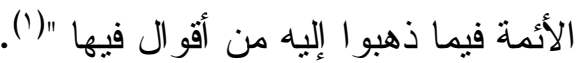
فتلمس أسباب الخلاف في المسائل الفقيه والأصولية تزيد في عمق الفقيه ونضجهاه،

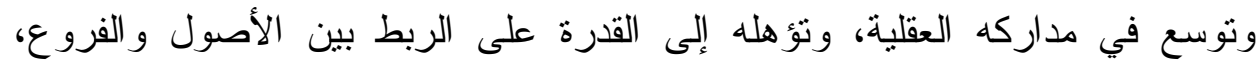

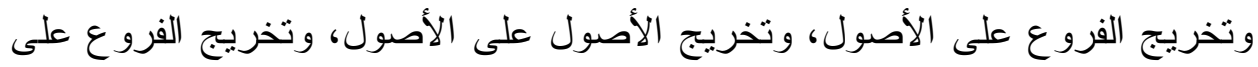

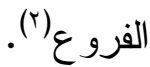

ومنذ أواخر القرن الثالث و الرابع الهجري ظهر الاهتمام بعلم الخلاف بين أصحاب المذاهب و الاهتمام بالنظر في مداركهم ومأخذهم في أقو الهم (َّ).

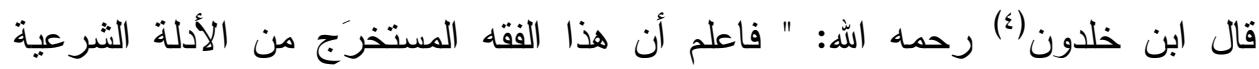
مفوّض إلى نظر المجتهدين ، و الخلاف بينهم في إصابة الحكم منها باختلاف مداركهم

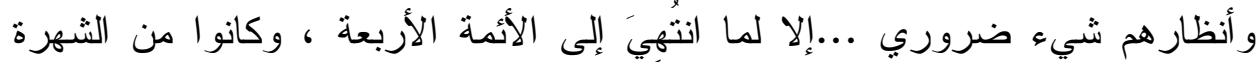

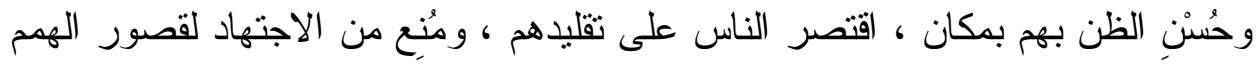

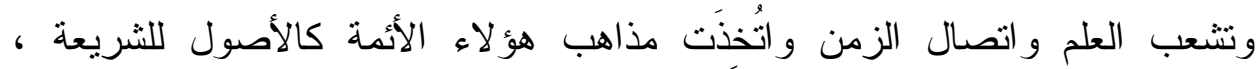

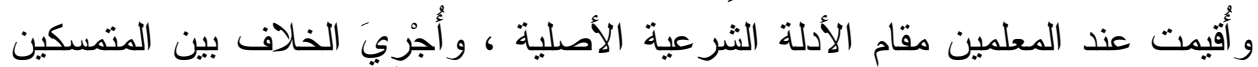
بها و الآخذين بأحكامها مجرى الخلاف في النصوص الثرعية و الأصولية الفقهية " (•). وقد حرص المحققين من أهل العلم قديماً وحديثاً على بيان أسباب الخلاف؛ لدفع تلكاف والك

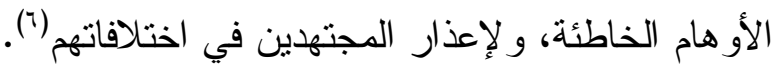

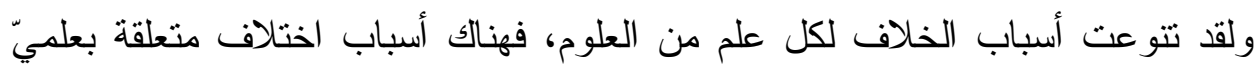

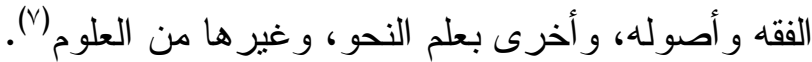

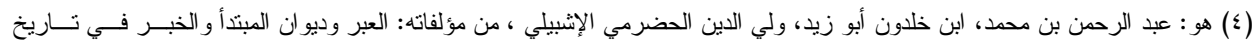

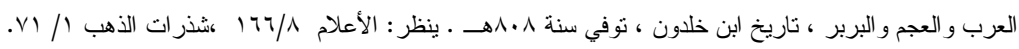

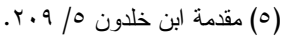

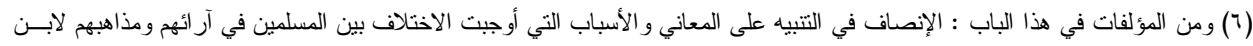

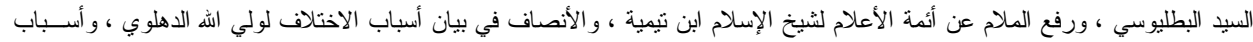

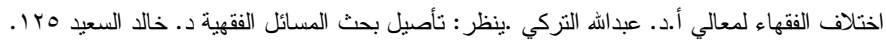

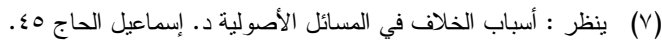


ومن أسباب الخلاف الو اقع بين حملة الثريعة(').

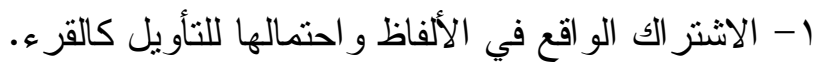
r- دور ان اللفظ بين الحقيقة و المجاز . r- دور ان الدليل بين الاستقلال بالحكم وعدمه. ع - دور انه بين العدوم و الخصوص. ه- اختلاف الرواية. 7- جهات الاجتهاد و القياس. V - دعوى النسخ و عدمه. ^- ورود الأدلة على وجوه تحتمل الإباحة وغيرها؛ كالاختلاف في الأذان، و التكبير على الجنائز (r). 9 - و ونالك أساب متعلقة بالاصطلاحات و المناهج. • 11 أسو أسباب متعلقة بالأصول العقدية.

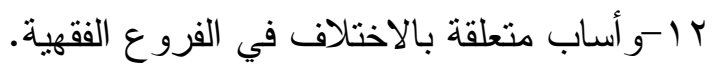
r ا أو أسباب متعلقة بالتعارض وض والابعل بالشتباه. ع ا - و أسباب متعلقة بالخلاف في القو اعد الأصولية.

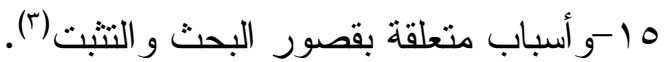
المبحث السادس: أسباب عدم الاعتداد بالخلاف. ضابط الخلاف المعتبر هو: النظر في الأدلة من حيث الاحتجاج بها، فما بُني على حُجة

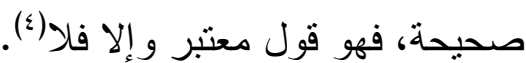

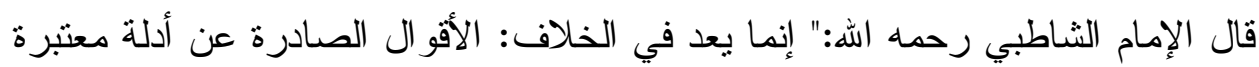

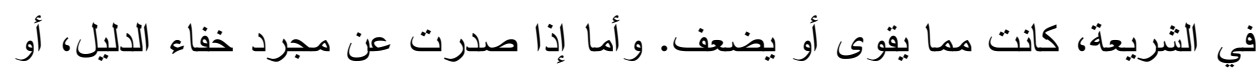
عدم مصادفته، فلا.

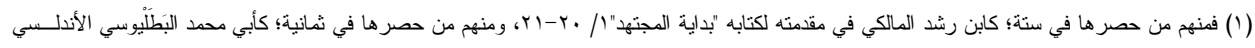

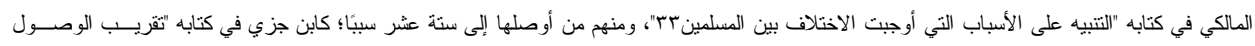

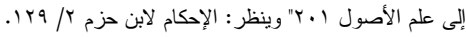

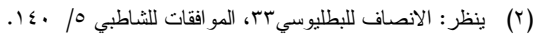

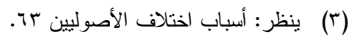

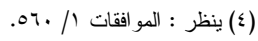


فلذلك قيل: إنه لا يصح أن يعتد بها في الخلاف، كما لم يعتد السلف الصالح بالخلاف

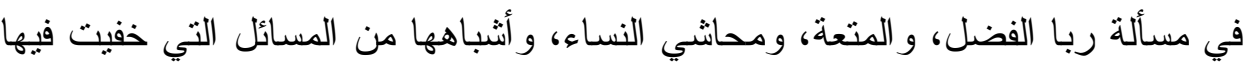
الأدلة على من خالف فيها "(').

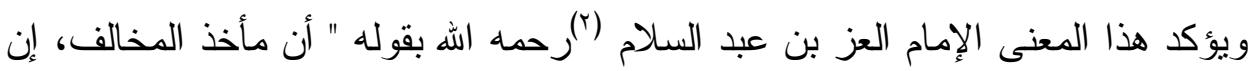

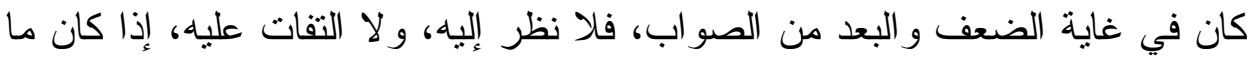

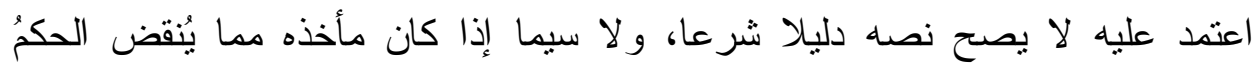

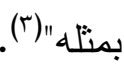
ويقول الإمام تاج الدين السبكي(؛) رحمه الله - في حديثه عن شرط الخلاف المعتبر -:"

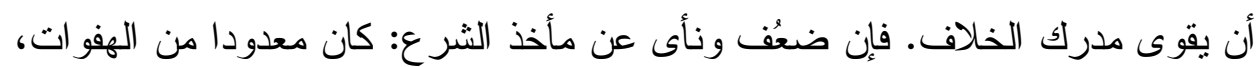

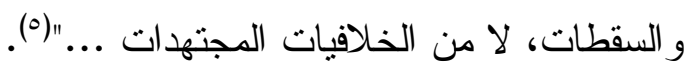
وقد بين الإمام الشاطبي رحمه الله أسباب عدم الاعتداد بالخلاف حيث قال:" من الخلاف ما لا يعتد به في الخلاف وهو ضرام ضربان

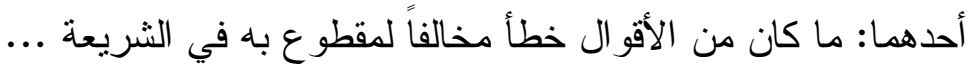
و الثاني: ما كان ظاهره الخلاف وليس في الحقيقة كذلك. و أكثر ما يقع ذلك في تفسير الكتاب و السنة فتجد المفسرين ينقلون عن السلف في معاني ألفاظ الكتاب أقوالاً مختلفة في الظاهر فإذا اعتبرتها وجدتها تتلاقى على العبارة

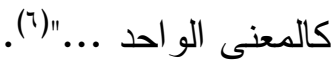

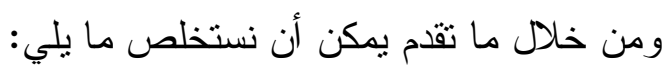

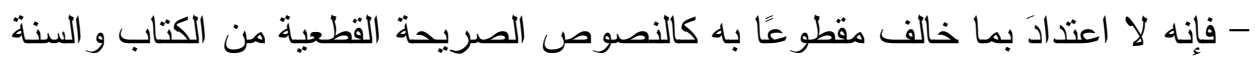
و الإجماع القطعي. 


$$
\text { - و لا اعتدادَ بخلاف سبيُهه عارضِ. }
$$

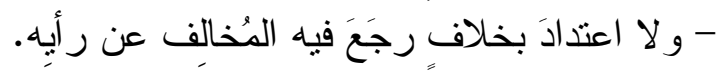

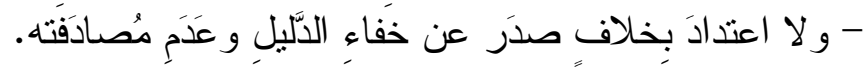

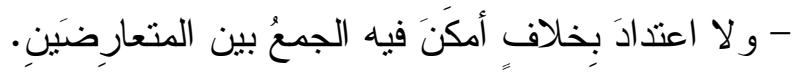
- و لا اعتداد بالأقو ال المهجورة و الضعيفة و الثاذة. - و لا اعتداد بالخلاف المناقض لمقاصد الثريعة (') المبحث السابع: القواعد والضوابط الأصولية في الخلاف. ذكر الأصوليون عدداً من القو اعد و الضوابط في الخلاف ومنها:

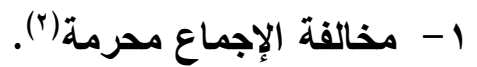

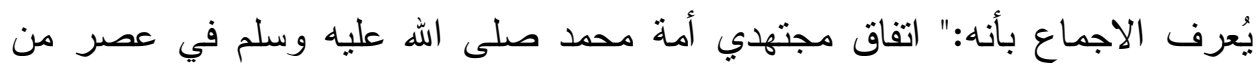

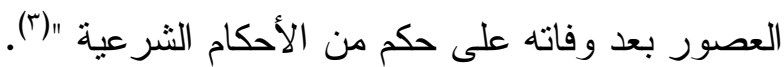
و الإجماع حُجة شرعية يحرم مخالفته (ء).

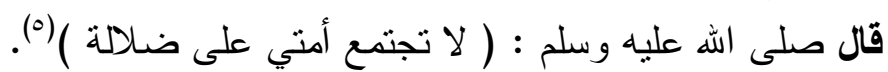

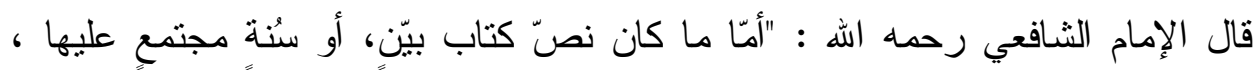

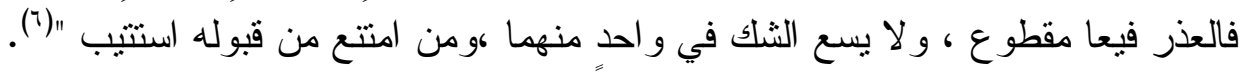

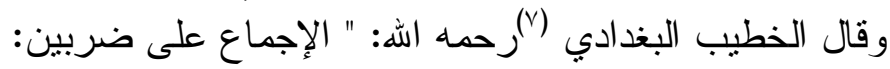

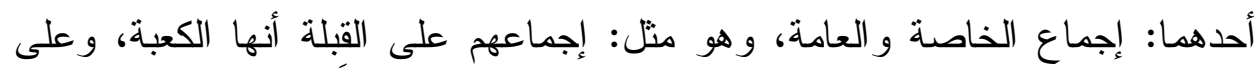

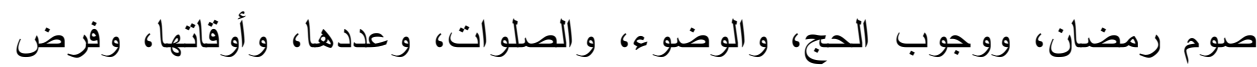
الز كاة، و أثنباه ذلك.

و الضرب الآخر : هو إجماع الخاصة دون العامة، منل ما اجتمع عليه العلماء من:

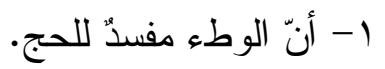


r- أن الوطء في الصوم مفسد للصوم.

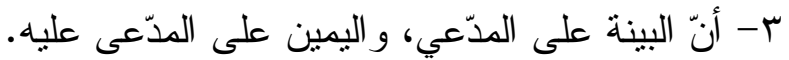

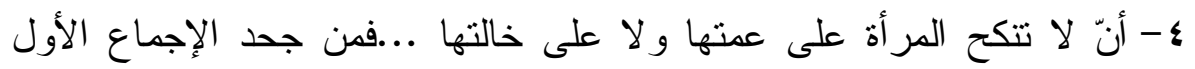

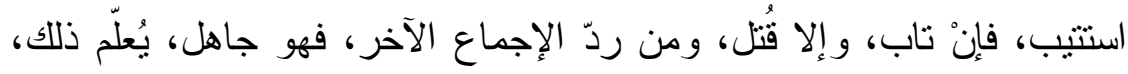

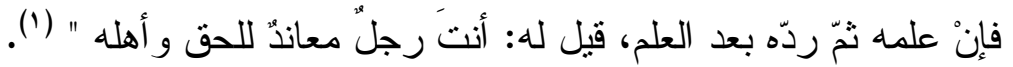

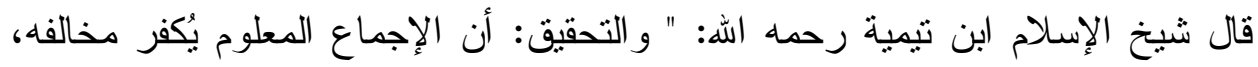

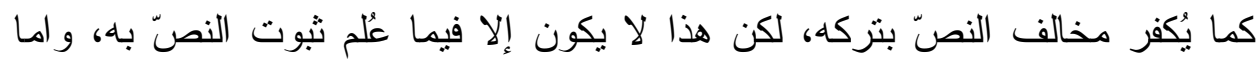

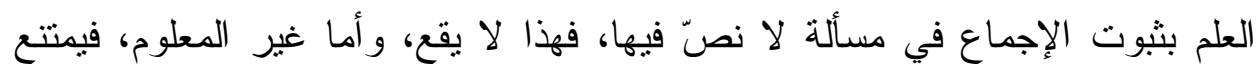

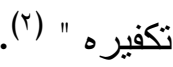

ومما تقدم يتبين: أنه يجب على -المجتهد-المفتي أن يعرف ما أجمع عليه العلماء، و لا

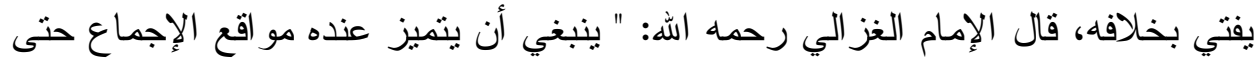

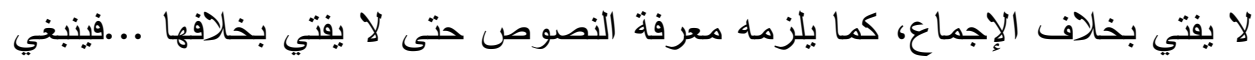

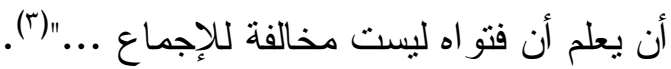

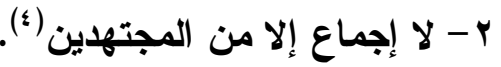

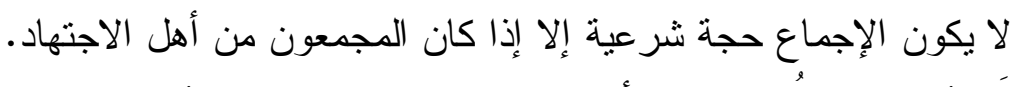

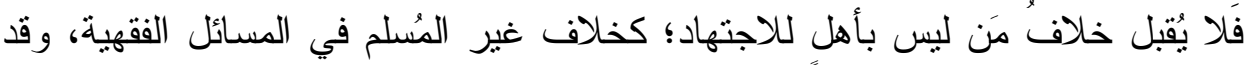

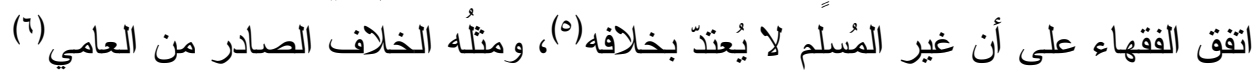

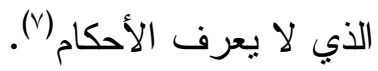
قال الإمام الشاطبي رحمه الهة:" الاجتهاد الواقع في الثريعة ضربان، أحدهما: الاجتهاد المعتبر شرعاً، وهو الصادر عن أهله الذين اضطلعو ا بمعرفة ما يفتقر الاجتهاد إليه.

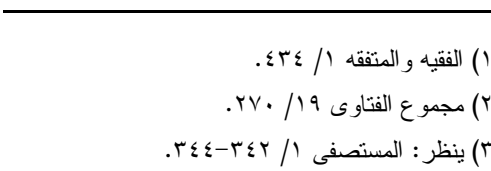

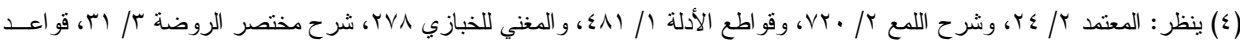

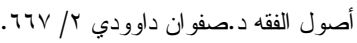

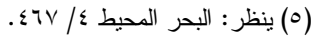

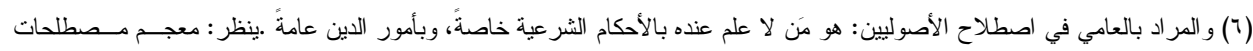
الأصوليين لسانو بVV

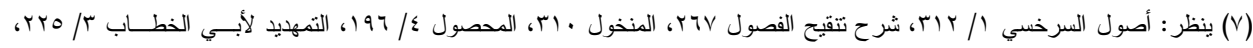
إرشاد الفحول Yr. 
و الثاني: غير المعتبر، وهو الصادر عمن ليس بعارف بما يفتقر الاجتهاد إليه، لأن

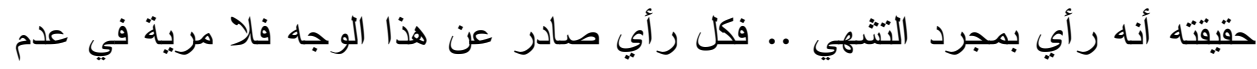

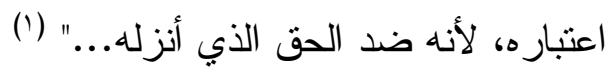

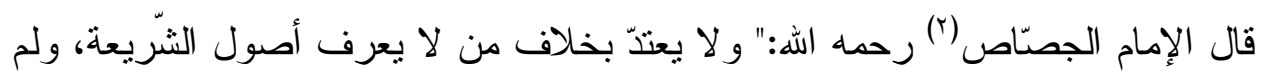

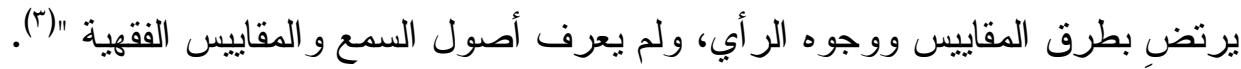
وقال الإمام ابن قدامة رحمه الله: " ومن يعرف من العلم مالا أثز له في معرفة الحكم -

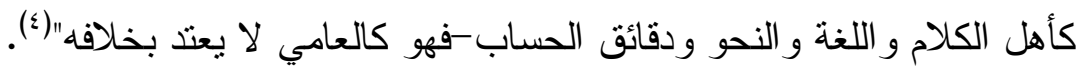

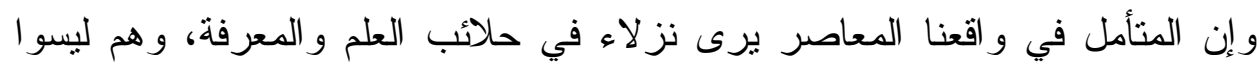

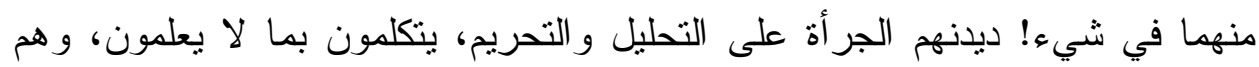
قليلي البضاعة في أحكام الثريعة، نر اهم يتحدثون عن عظيم المسائل في جميع الفنون،

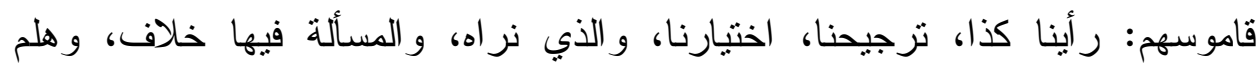

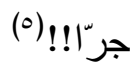
فهؤ لاء و أضر ابهم كالعو ام لا يعتد بهم في الخلاف.

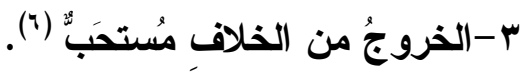
معناه: العمل بدليل المخالف في المسألة من المذاهب الفقهية المعتبرة، بما لا يبطل دليل

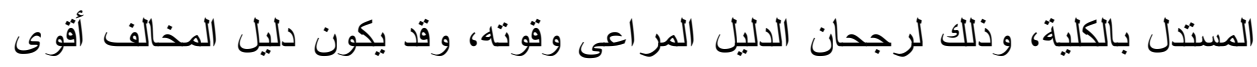

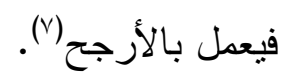
و هذا الضابط نصنَ عليها كثير من الأصوليين في كتبهم، وقد ذهب جماهير الفقهاء إلى

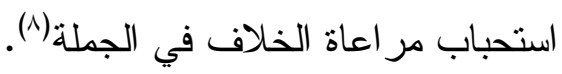

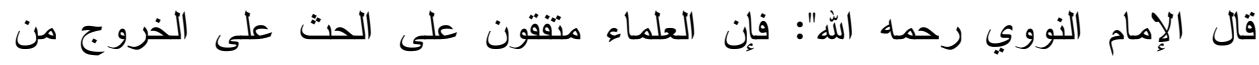

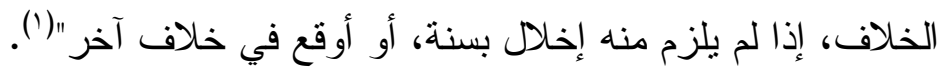

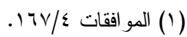

$$
\begin{aligned}
& \text { : (ال) }
\end{aligned}
$$

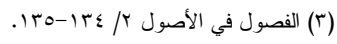

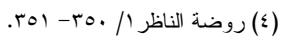

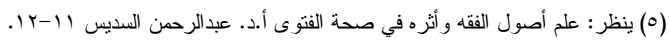

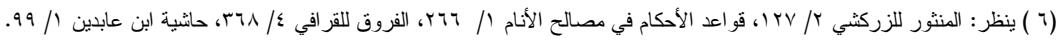

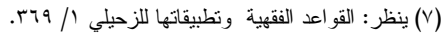

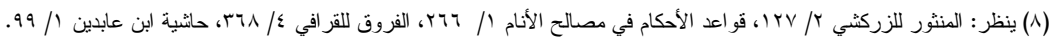




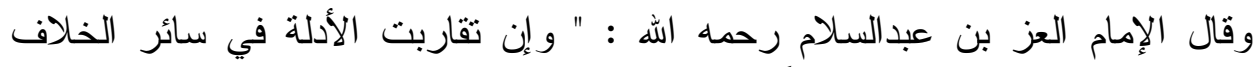

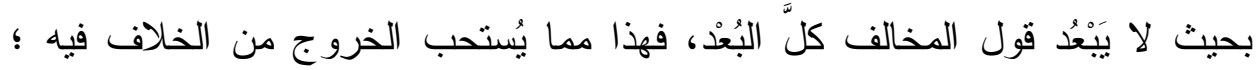

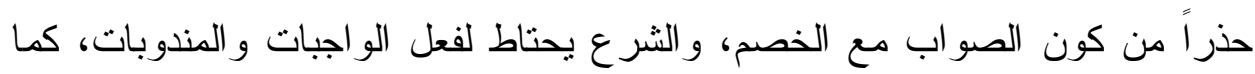

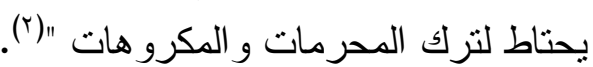

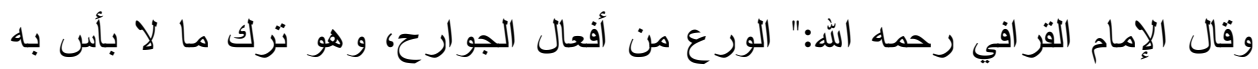
حذرا مما به البأس... وهو مندوب إلبه، ومنه الخروج عن خلاف العلماء بحسب

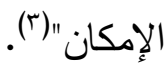
وقال الإمام تاج الدين السبكي رحمه الله:" ومن القو اعد ما اشتهر في كلام كثيرٍ من الثن

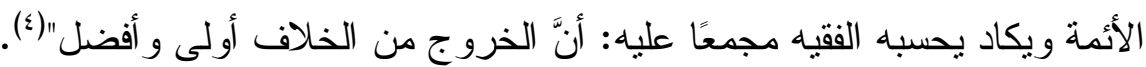

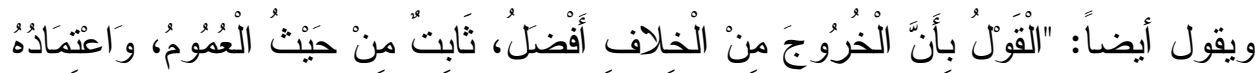

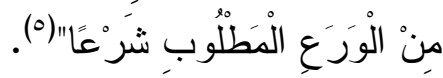

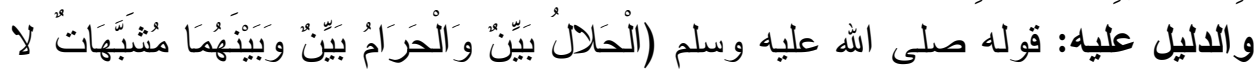

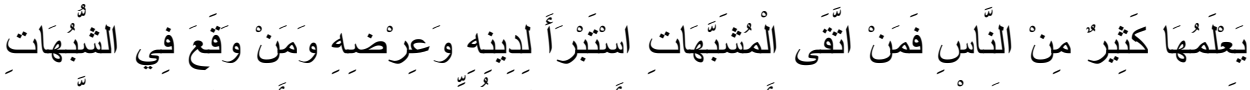

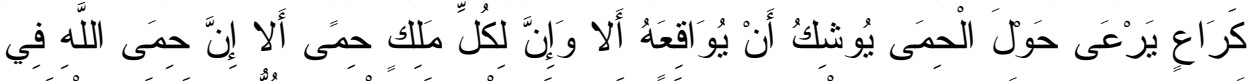

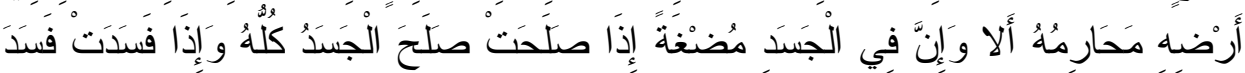

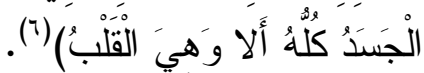

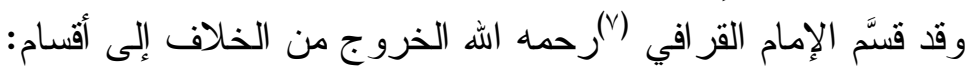
القسم الأول: أن يكون الخلاف في التحريم و الإباحة، فالخروج من الخلاف بالاجتتاب أفضل.

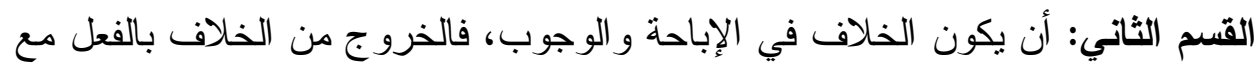
اعتقاد الوجوب حتى يجزئ عن الو اجب أفضل. 
القسم الثالث: أن يكون الخلاف في الاستحباب و الحرمة: فالخروج من الخلاف بالترك أفضل. القسم الرابع: أن يكون الخلاف في الكراهة والوجوب: فالخروج من الخلاف بالفعل

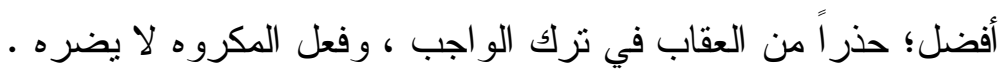

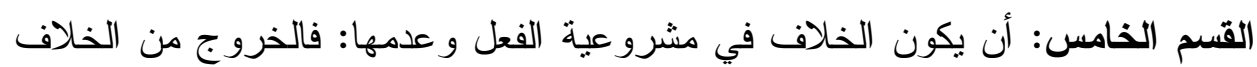
بالفعل أفضل؛ لأن القائل بالمشروعية مثبت لأمر لم يطلع عليه النافي، و المثبت مقدَّم على النافي كما هو معلوم. غير أنَّ الخروج من الخلاف ليس على بابه، بل له ضو ضوابط وشروط وهي:

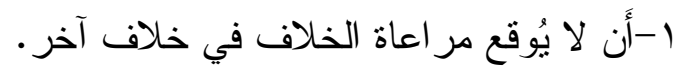

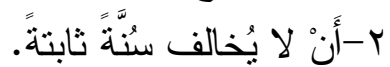

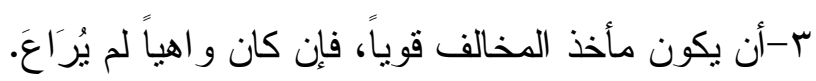

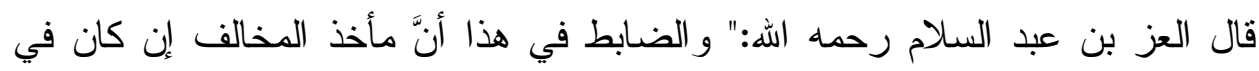
غاية الضعف و البعد من الصو اب فلا نظر إليه و لا التفات عليه "( (').

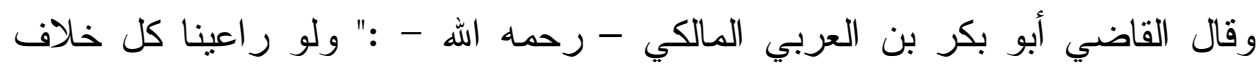

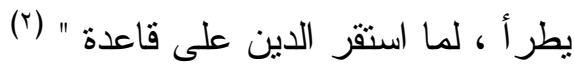

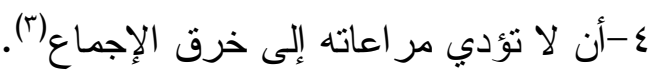

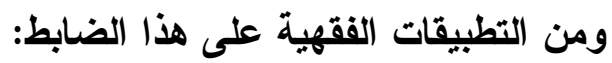

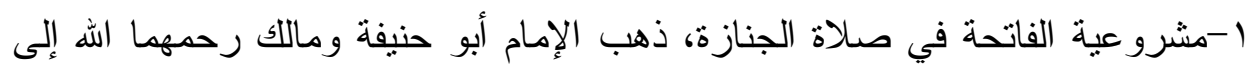

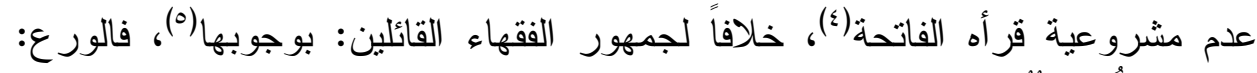

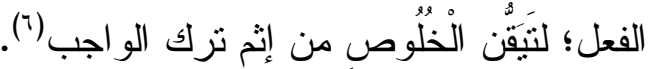

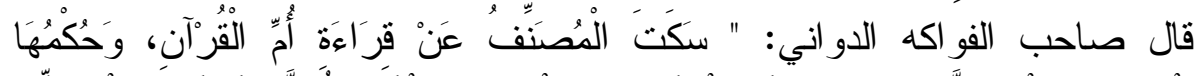

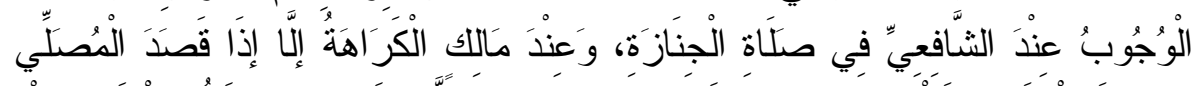

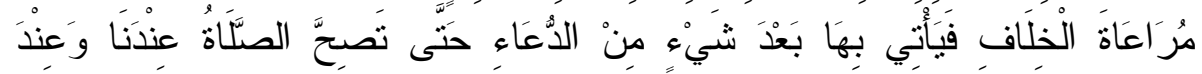




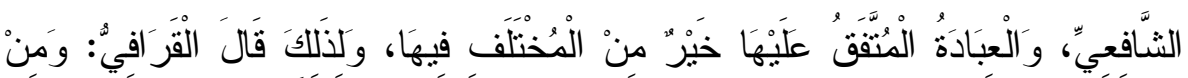

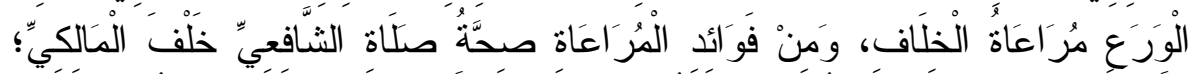

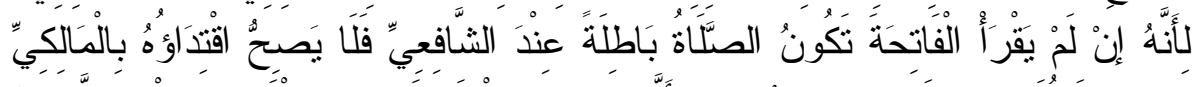

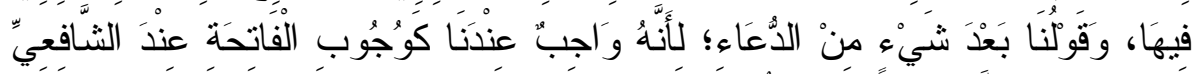

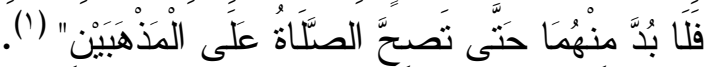

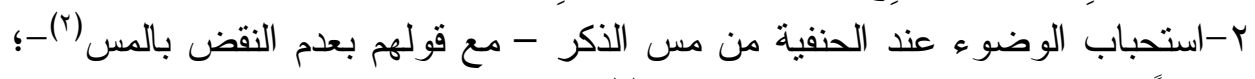

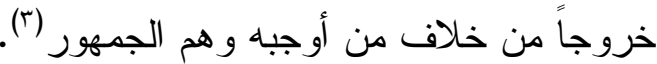

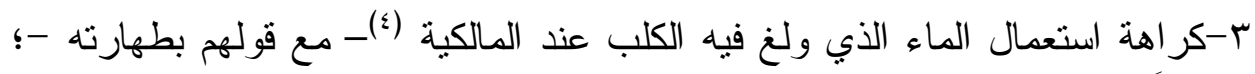

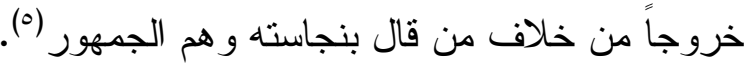

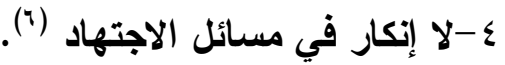

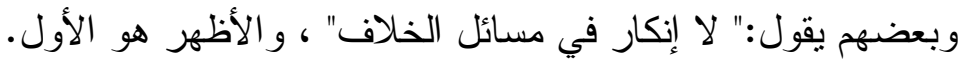

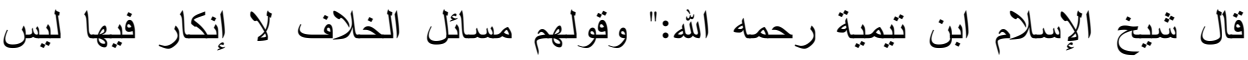

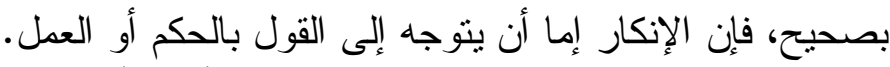

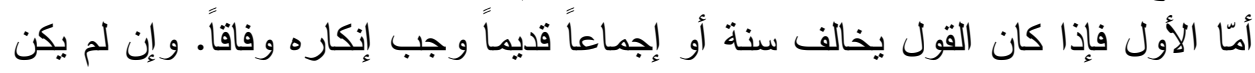

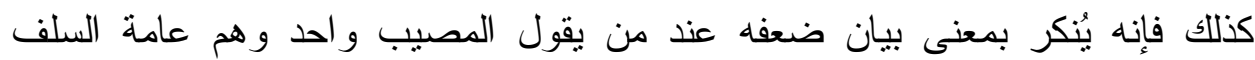
و الفقهاء. وأما العمل فإذا كان على خلاف سنة أو إجماع وجب إنكاره أيضاً بحسب درجات

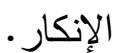
أما إذا لم يكن في المسألة سنة و لا إجماع وللاجتهاد فيها مساغ لم ينكر على من عمل بها مجتهاً أو مقلداً. و إنما دخل هذا اللبس من جهة أن القائل بعتقد أن مسائل الخلاف هي مسائل الاجتهاد،

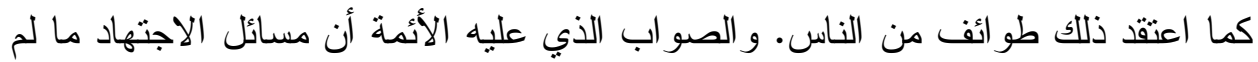

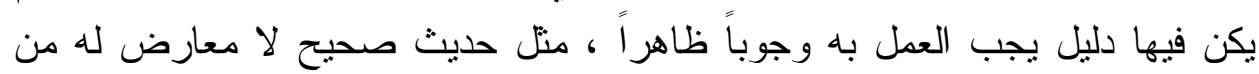


جنسه ، فيسوغ إذا عدم ذلك فيها الاجتهاد لتعارض الأدلة المتقاربة أو لخفاء الأدلة

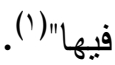
ويؤكد هذا الإمام ابن القيم رحمه الله بقوله:" وقولهم: "إن مسائل الخلاف لا إنكار فيها"

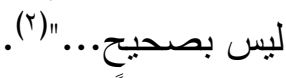
ويقول أيضاً:" فإذا كان القول يخالف سنة أو إجماعاً شائعاً وجب إنكاره اتفاقاً "(").

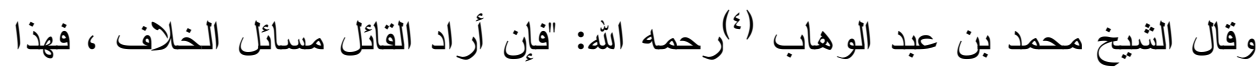

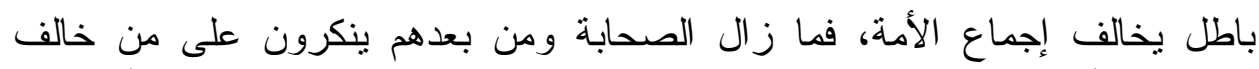

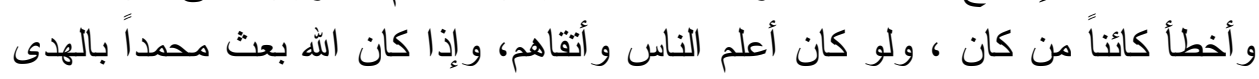

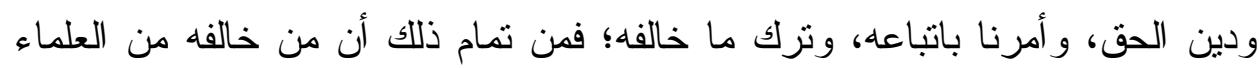

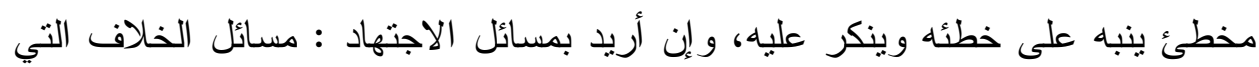

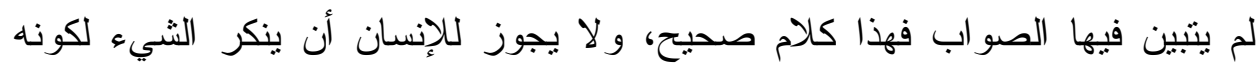

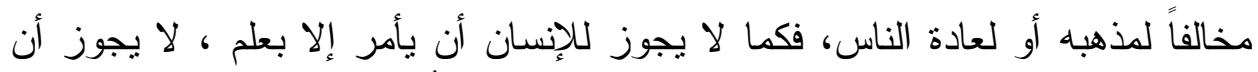

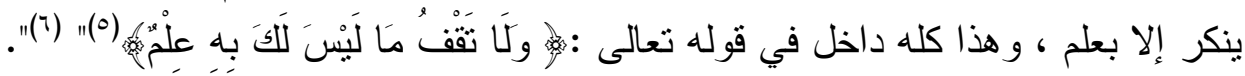

تتقسم المسائل التي اختلف فيها أهل العلم إلى قسمين:

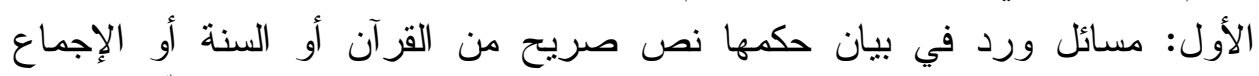

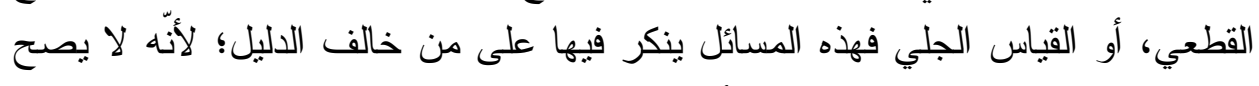

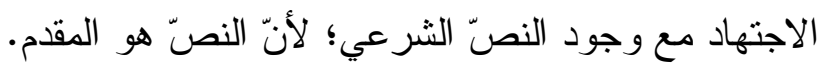

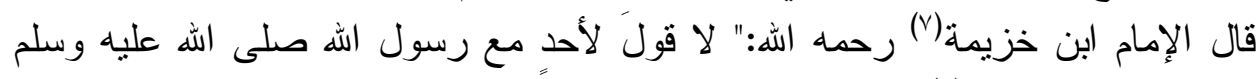

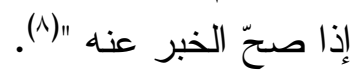
ومن الأمثلة على ذلك: 1- تأويل أسماء الله عز وجل ذلك: وصفاته.

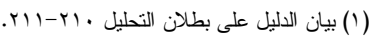

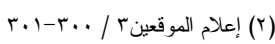

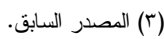

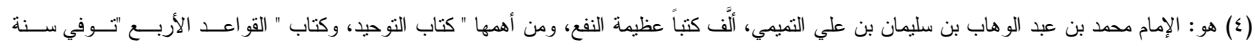

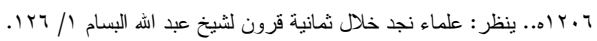

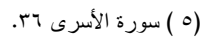

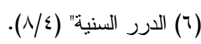

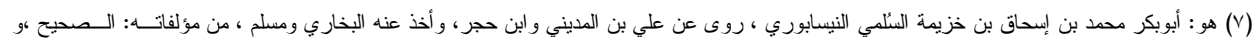

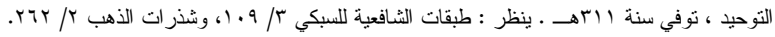

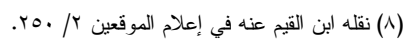


r- رد بعض نصوص السنة و إنكارها، كأحاديث الثفاعة، ونعيم القبر وعذابه،

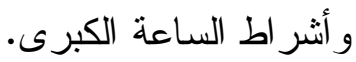

r- إباحة الفو ائد البنكية، كشهادات الاستثمار ؛ بحجة التمويل لخطة التتمية الاقتصادية. ع - و القول بجو از تقديم الخطبة على صلاة العيد. 0- القول بجو از سماع المعازف. القسم الثاني: مسائل لم يرد ببيان حكمها دليل صريح من الكتاب أو السنة أو الإجماع أو القياس الجلي، أو ورد بحكها دليل من السنة، ولكنه مختلف في تصحيحه، أو من فئان

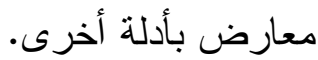

فهذه المسائل تحتاج إلى نوع اجتهاد ونظر وتأمل لمعرفة حكمهاهو لا يُنكر فيها على المخالف.

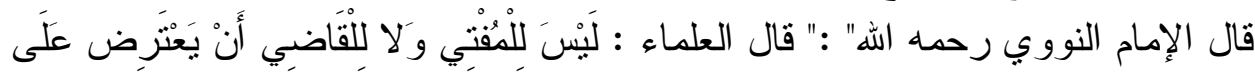

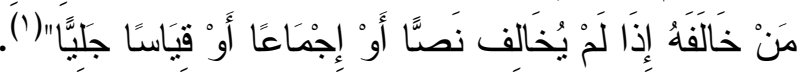
ومن الأمنلة على ذلك:

1- نقض الوضوء من عن مس الأكر. r ب و إفساد الصوم بالحجامة.

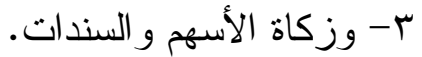
ع - وسقوط المبيت عن الحاج إذا لمن لم يجد مكاناً مناسباً في منى يبيت فيه. ه- و المعاملات المالية المعاصرة.

فهذه المسائل و أمثالها مما لم ترد نصوص صراته صريحة بييان حكمها هي التي لا ينكر فيها

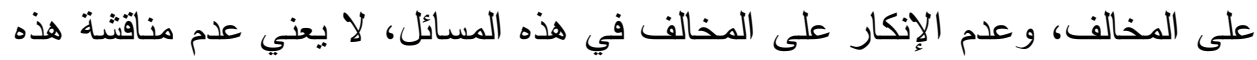
المسائل و التباحث فيها، بل لم يزل العلماء منذ فجر التاريخ إلى يومنا هذا تعقد بينهم

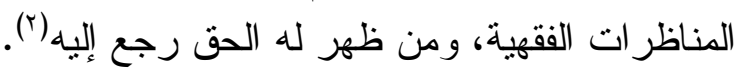
ه-الاحتجاج بالخلاف على جواز الفعل محرم (َ).

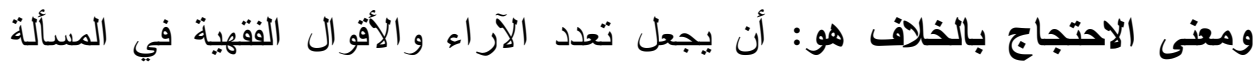

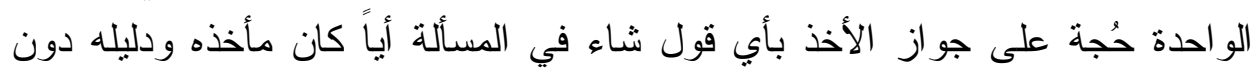

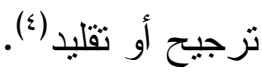

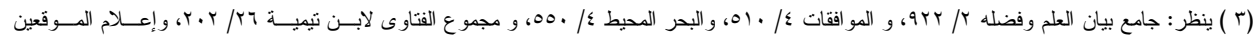


قال الإمام الثاطبي رحمه الها: " الاعتمادُ في جواز الفعل على كونه مختلفاً فيه بين

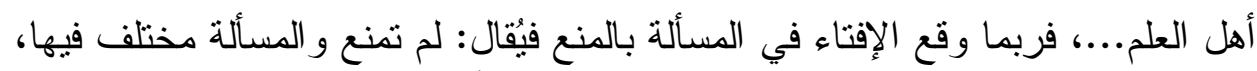

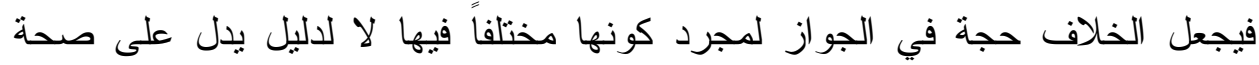

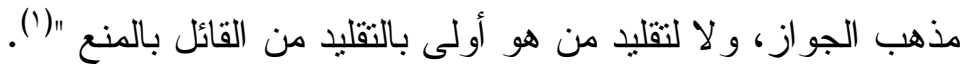

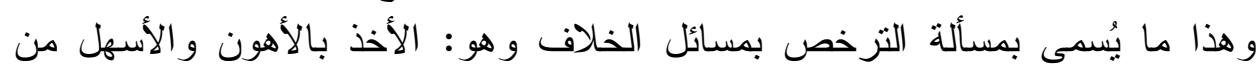

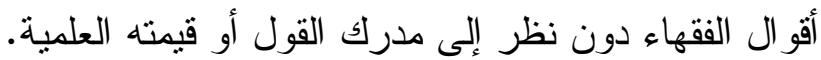

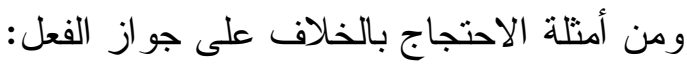
ا ب - جواز الحيل الربوية.

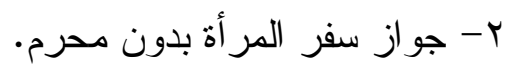
r- دعوى إسقاط الو لاية عن المر أة.

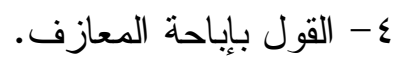
ه- القول بإباحة الاختلاط بين الرجال و النساء. وكل هذه الأمثلة وغيرها كثير؛ بدعوى وقوع الخلاف بين الفقهاء، وكثر التحايل على بلى بلاه

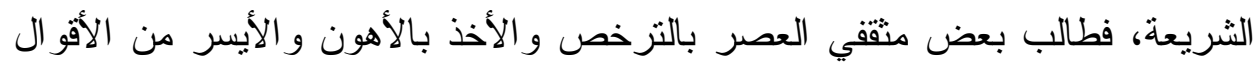

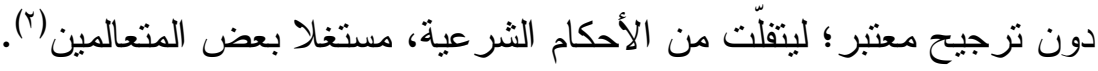

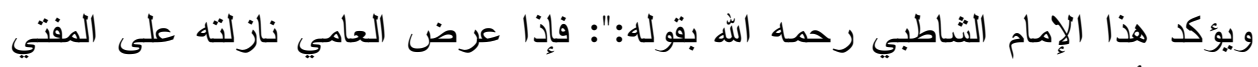

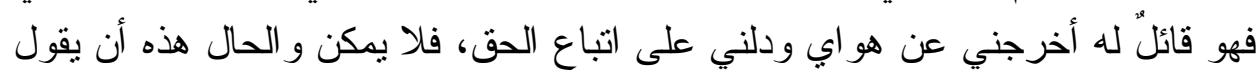

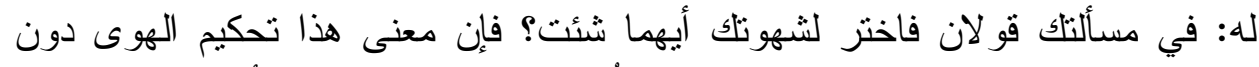

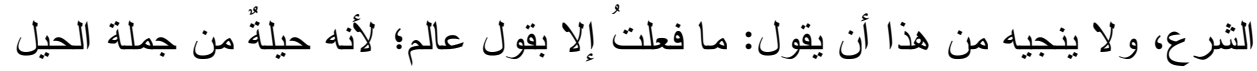

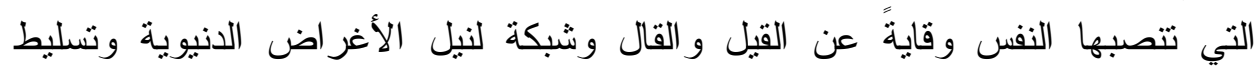

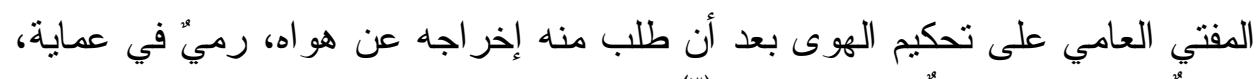
وجهل بالثريعة، و غش" في النصيحة "(").

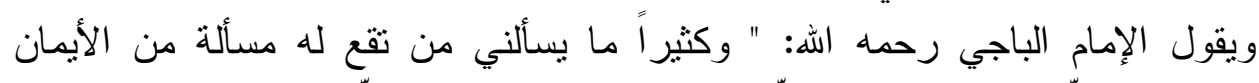

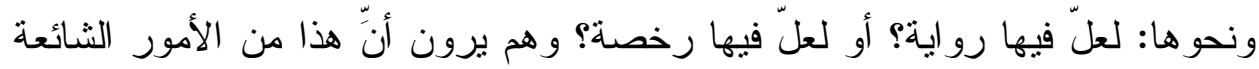

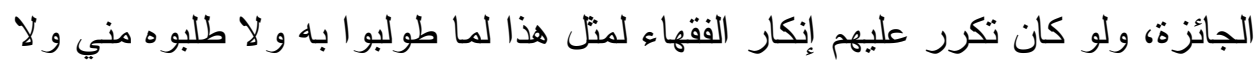

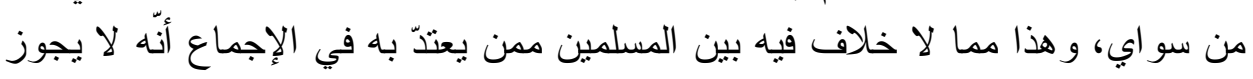




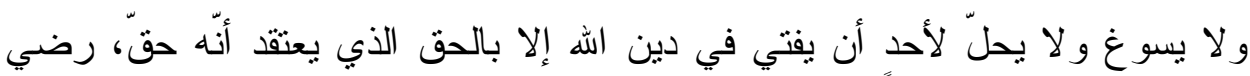

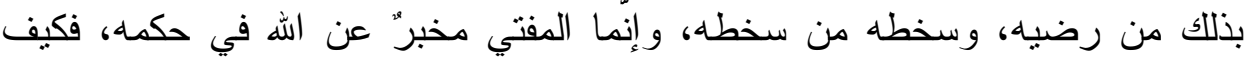

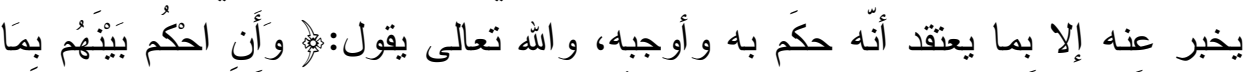

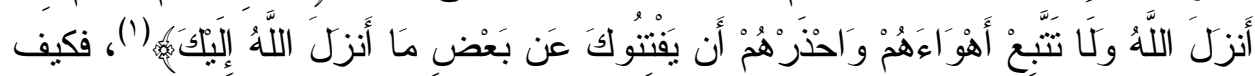

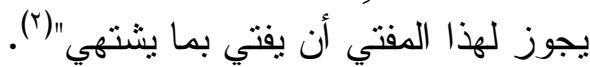

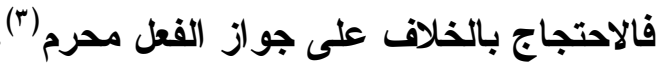

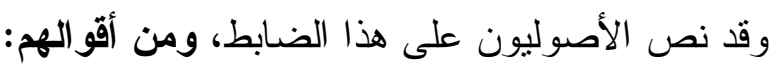

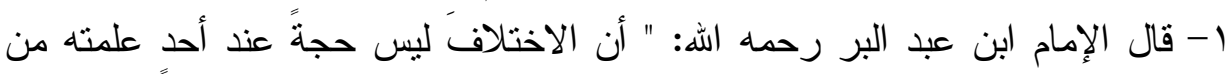

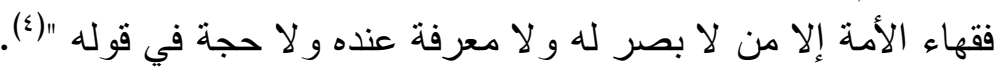

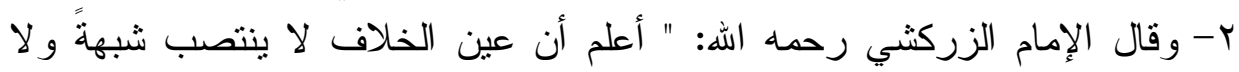

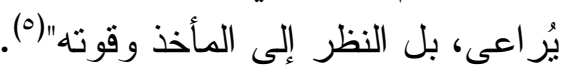

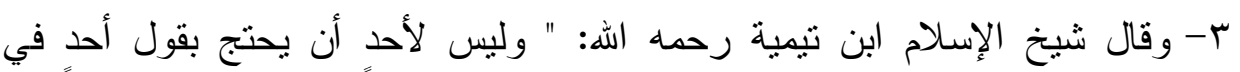

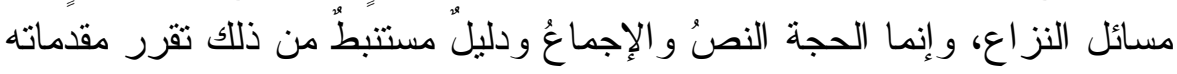

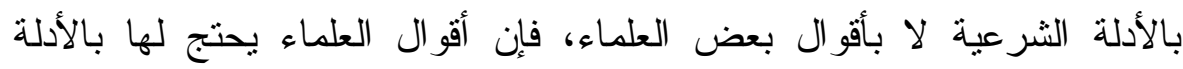

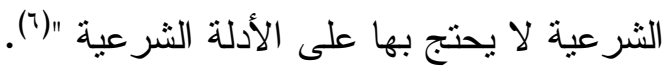

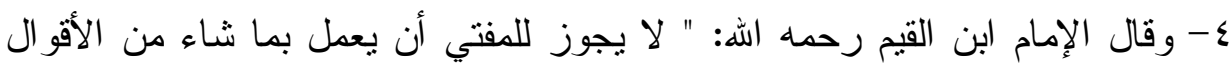

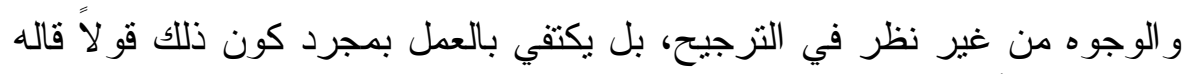

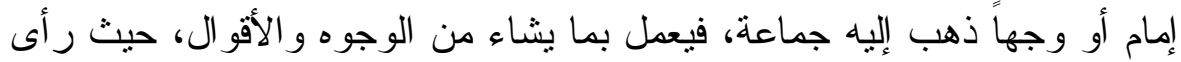

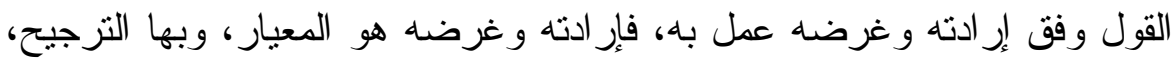

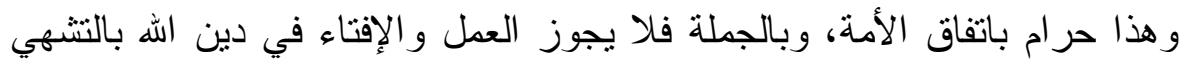

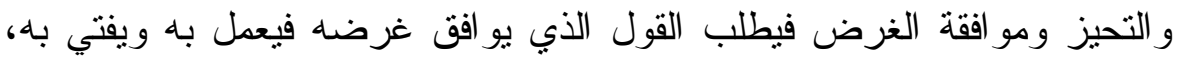
وهذا من أفسق الفسوق و أكبر الكبائر"((V).

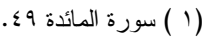

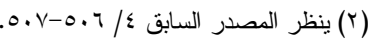

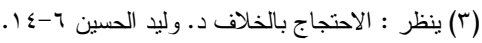

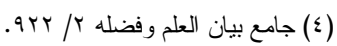

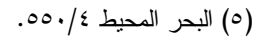

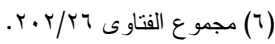

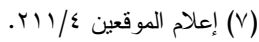




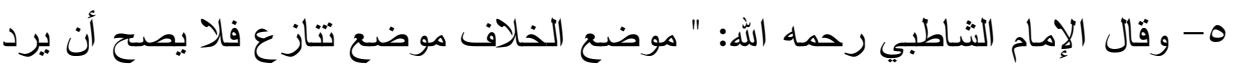
إلى أهو اء النفوس، و إنما يرد إلى الثريعة، وهي تبين الراجح الهُ من القولين فيجب

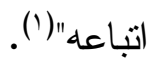

\section{צ- آلا خلاف في القطعيات (؟).}

القطع لغة : لفظ " القطع" يدل على " الصّرم و إبانة شيء من شيء " ، يقال : قطعت

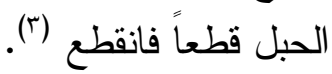

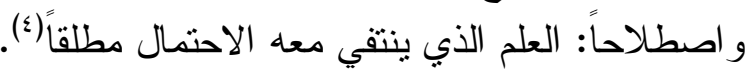

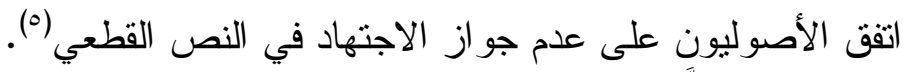

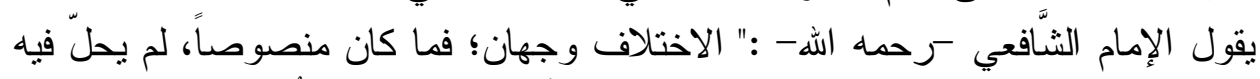

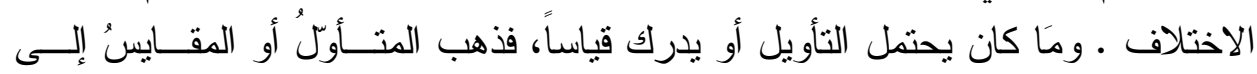

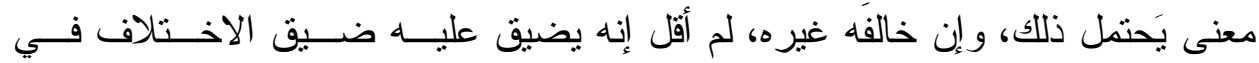

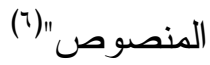

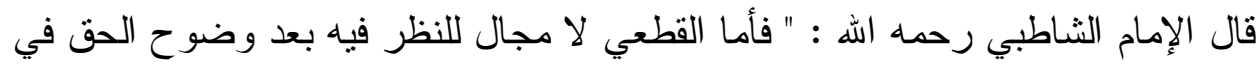

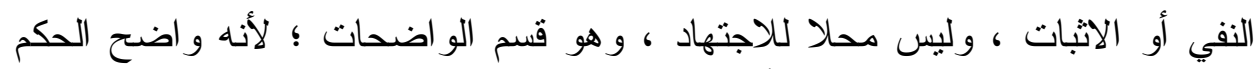

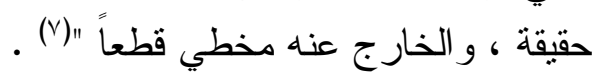

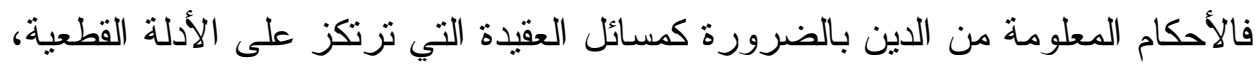

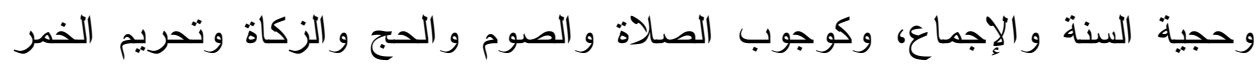
و الربا و الزنا. المخالف فيها آثم، و المصيب فيها و واحد. قال الإمام الغز الي رحمه الله : " فإن هذه مسائل أدلتها قطعية ، و المخالف فيها آثم الثم "(^).

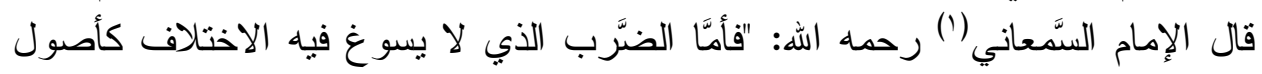

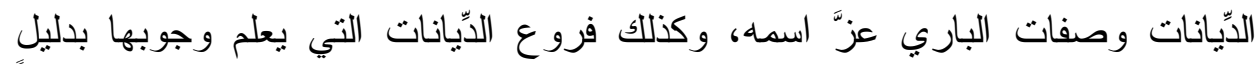




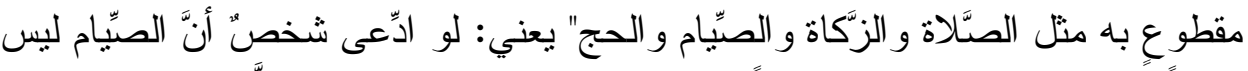

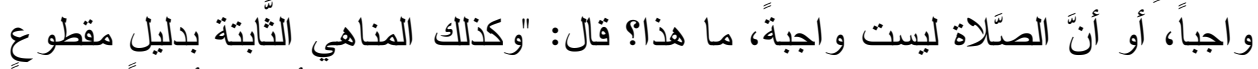

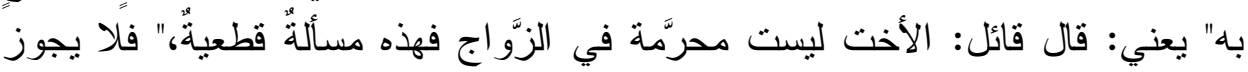

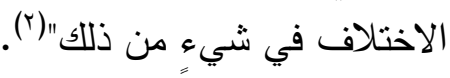
ومما تقدم يتبين: أنَ الدليل القطعي هو الدليل اليقيني الذي يفيد العلم، و لا يُقَدَر على رده

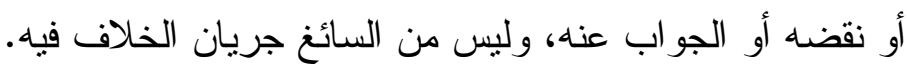

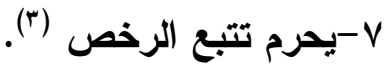

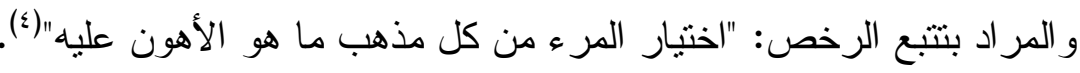

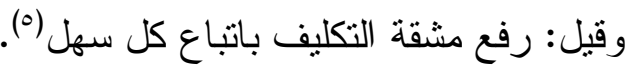
أو بأنه: "ما جاء من الاجتهادات المذهيبة مبيحاً لأمرٍ في مقابلة اجتهادات أخرى

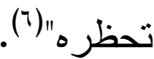

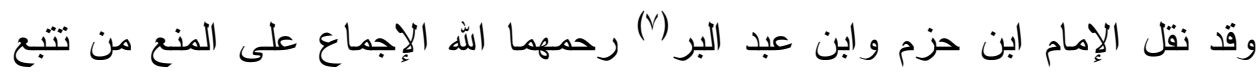
الرخص، و الأخذ بما يو افق الهوى و والغرض من ألقان أقو ال العلماء (^).

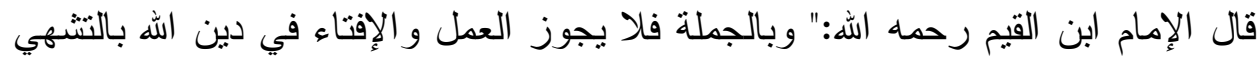

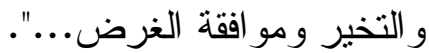

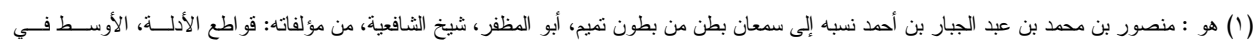

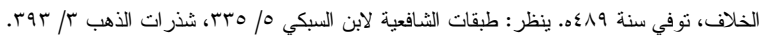

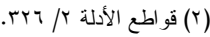

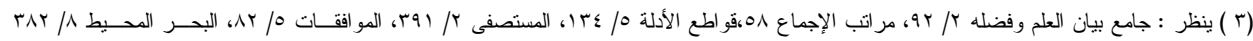

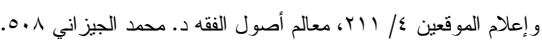

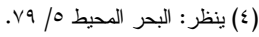

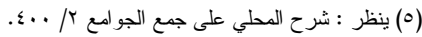

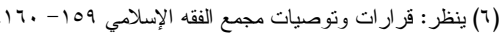

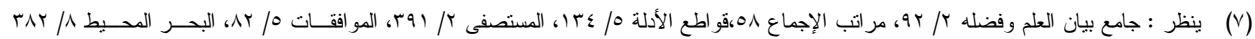

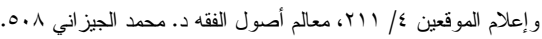
(^) وذهب الإمام السرخسي و ابن الهمام و ابن عبد الثكور و أمبر باد شاة من الحنفية إلى جو از تثبع الرخص . وذهب بعض العلماء إلى جواز الأخذ بالرخص بشروط منها:

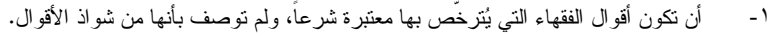
r- - أن تقوم الحاجة إلى الأخذ بالرخصة دفعاً للمشقة، سو اء أكانت حاجة عامة للمجتمع أم خاصة أم فردية.

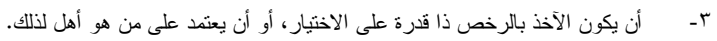

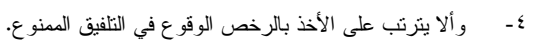

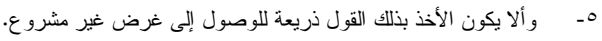

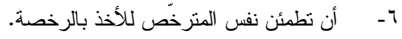

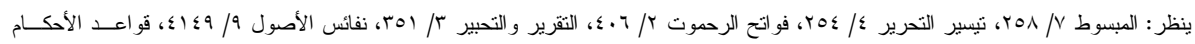

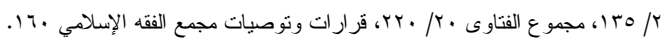


وقال ابن النجار الفتوحي رحمه الله: " ويُفْسُق بتتبع الرخص؛ لأنه لا يقول بإباحة جميع

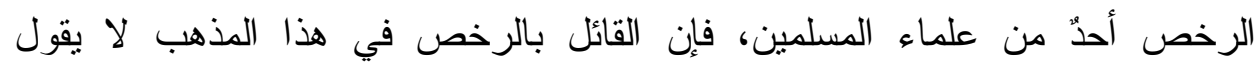
بالرخصة الأخرى التي في غيره"(').

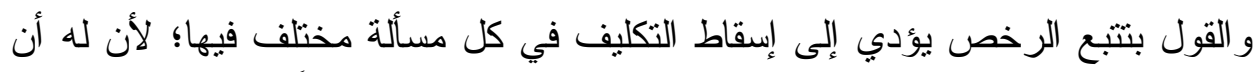

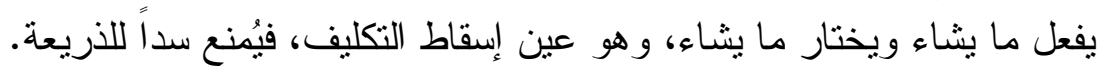

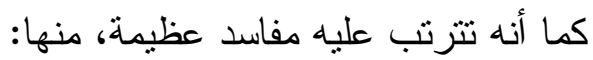

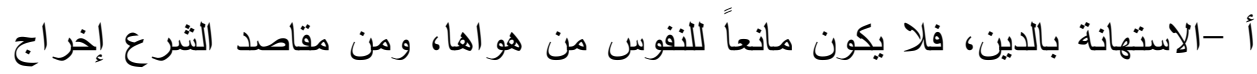

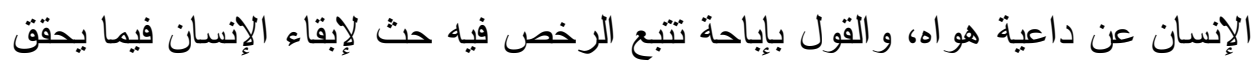
هو اله

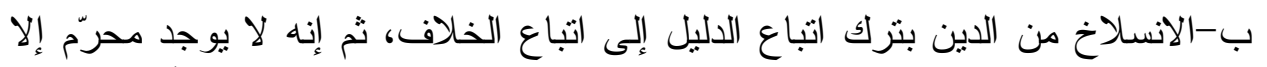

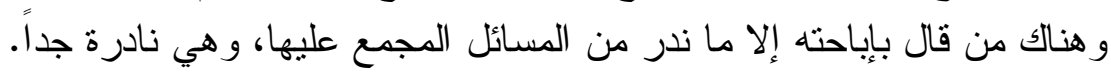

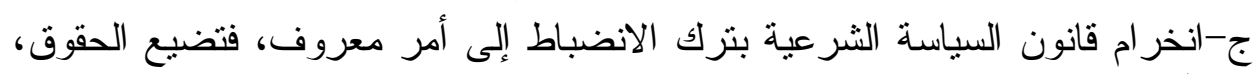
وتعطلّ الحدود، ويجترئ أهل الفساد.

د-إفضائه إلى القول بتلفيق المذاهب على ودئز اهل وجه يخرق إجماعهم (؟).

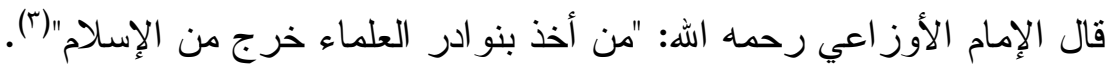




\section{الخاتمة و النتائج}

الحمد لله ربّ العالمين، و الصلاة و السلام على أثرف الأنبياء وسيد المرسلين، سيدنا

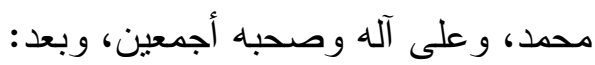

في هذا المقام يحسن الإشارة إلى أهم النتائج المستفادة من هذا البحث وصد ومنها:

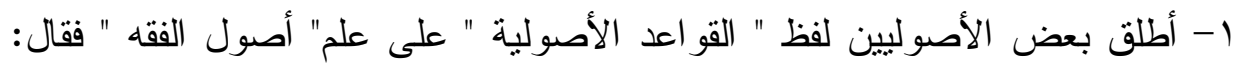
أصول الفقه: القواعد التي يتوصل بها إلى استتباط الأحكام الثرعية من الأدلة.

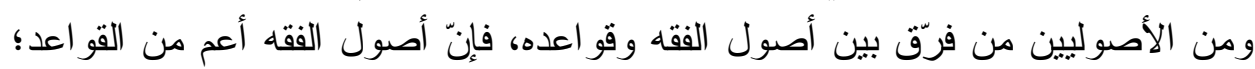

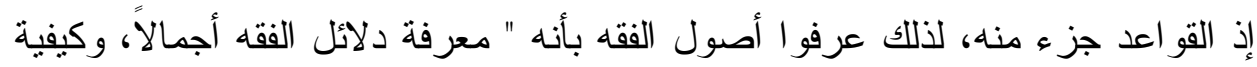
الاستفادة منها، وحال المستقيد.

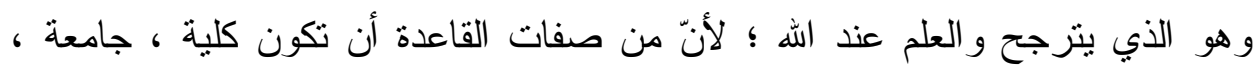
موجزة الألفاظ ، و أقرب تعريف للقاعدة الأصولية " قضية كلية يتوصل بها لإن إلى استتباط الأحكام الشرعية الفرعية من أدلتها التقصيلية " .

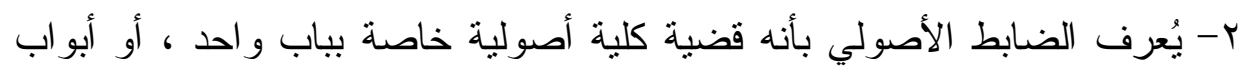
متعددة منطبقة على جميع جزئياتها .

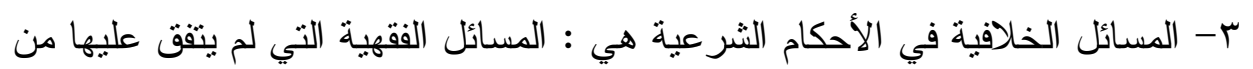

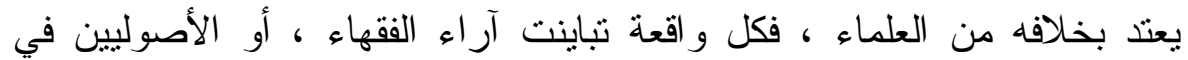

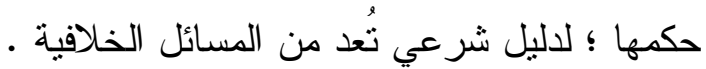

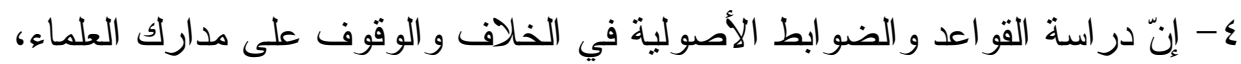

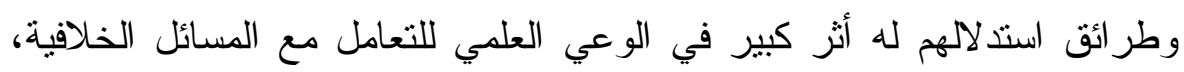

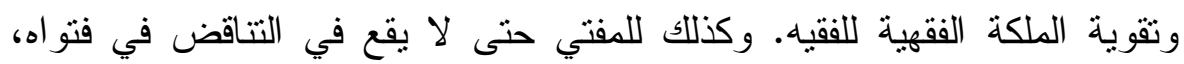

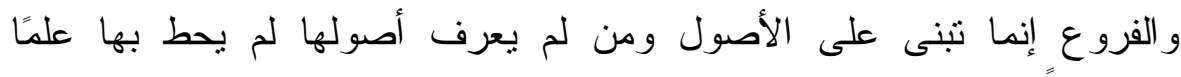

$$
\text { و واستتباطاً. }
$$

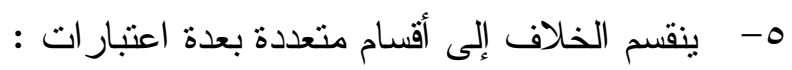

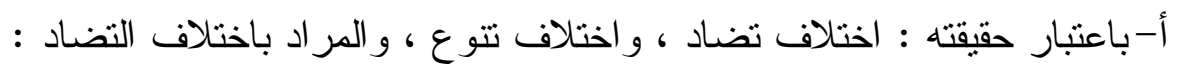

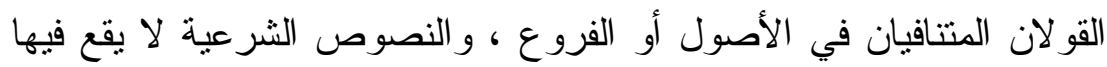

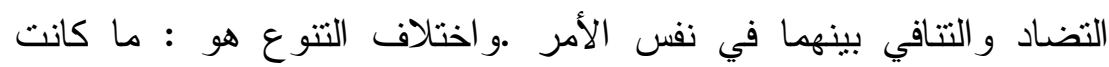
المخالفة فيه لا تقتضي المنافاة ، و لا تقتضي إيطال أحد القولين .

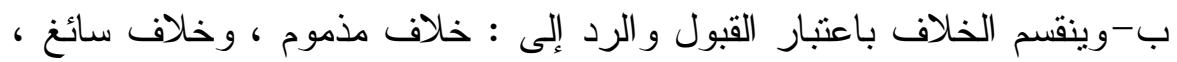
والخلاف المذموم وهو الأقوال الصادرة عن اجتهاد غير مأذون فيه شرعاً 
كخلاف الكفار ، و أهل الأهو اء ، و الخلاف الواقع في المسائل التي لا مساغ

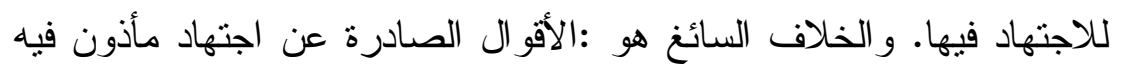

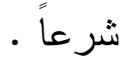

ت-وينقسم الخلاف كذلك باعتبار نتائجه وثماره إلى : خلاف معنوي ، وخلاف

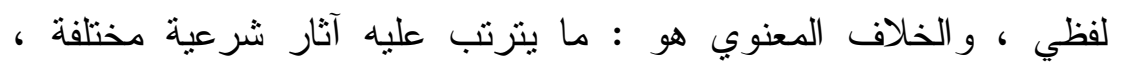
و الخلاف اللفظي هو : ما يرجع فيه الخلاف إلى التسمية و الاصطلاح الفقهي

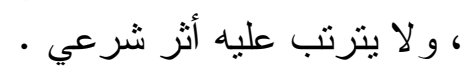

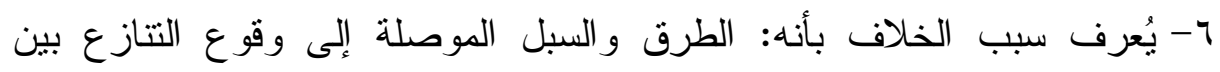

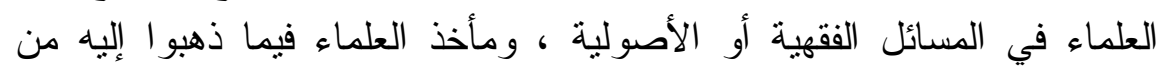

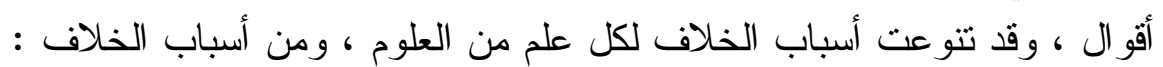

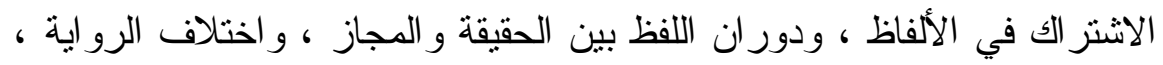

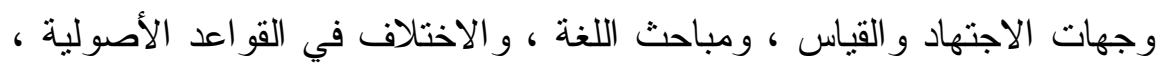

$$
\text { و غير ها كثير }
$$

V- ضابط الخلاف المعتبر هو : النظر في الأدلة من حيث الاحتجاج بها ، فما بُني

$$
\text { على حجة صحيحة ، فهو قول معتبر و إلا فلا . }
$$

1- ذكر الأصوليون عدداً من القو اعد الأصولية في الخلاف ومنها: أ-مخالفة الاجماع محرمة. ب- لا إجماع إلا من المجتهدين.

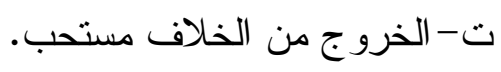
ث- لا إنكار في مسائل الاجتهاد.

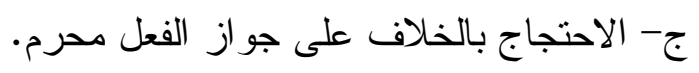
ح- لا خلاف في القطعيات. خ- يحرم تتبع الرخص.

وفي نهاية المطاف أوصي بالاهتمام بالقو اعد الأصولية، وخاصة ما يتعلق بجانب الخلاف، و استخلاص ضو ابطه وقو اعده، وفق منهجية علمية سليمة.

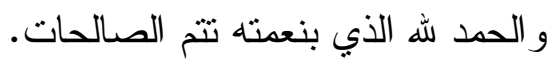




\section{فهرس المصادر والمراجع}

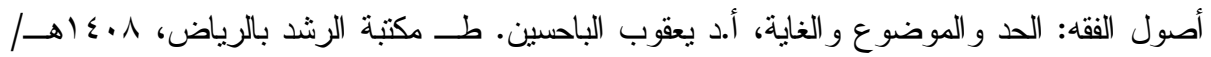
.01911

أثنز الاختلاف في القواعد الأصولية في اختلاف الفقهاء ، د. مصطفى الخنهؤسسة الرسالة ، الطبعة

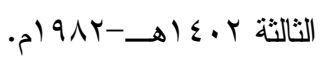

الاحتجاج بالخلاف، د. وليد بن علي الحسين ،جامعة القصيم ،طا

ه الإحكام في أصول الأحكام ، لأبي محدد علي بن حزم الظاهري، دار الكتب العلمية ، بيروت ، لبنان.

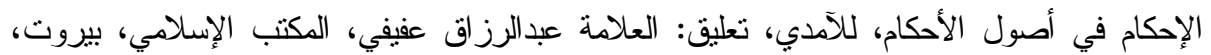

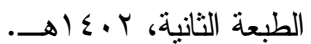

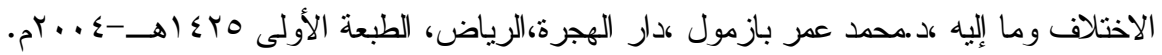

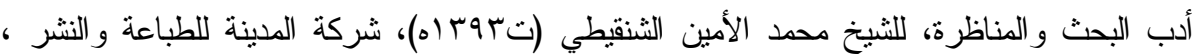

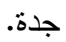

إرشاد الفحول إلى تحقيق علم الأصول ، للإمام محد بن علي الثنوكاني ، تحقيق : محمد البدري ،

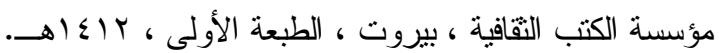

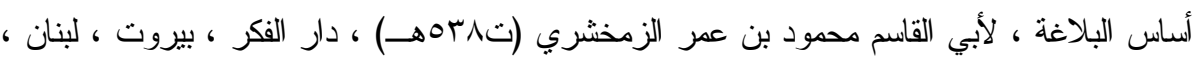
. $\rightarrow 10$ أسباب اختلاف الأصوليين مر اسة تطيقية نظرية ،د. ناصر الودعاني ،رسالة دكتور اة من جامعة الإمام

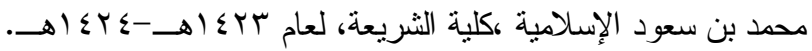
أسباب الخلاف في المسائل الأصولية المتعلقة بالأدلة المتفق عليها و الأدلة المختلف فيها، د. إسماعيل

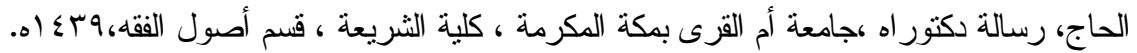

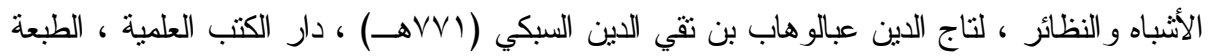

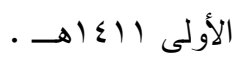
الأتباه و النظائر ، لعبدالرحمن بن أبي بكر السيوطي (ت (1) وه) ، دار الكتب العلمية ، الطبعة الأولى $.01 \leqslant 11$ الأثباه و النظائر على مذهب أبي حنيفة ، لابن نجيم ، دار الكتب العلمية ، بيروت ، 0. ــ اهـ.

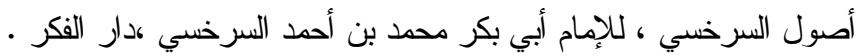




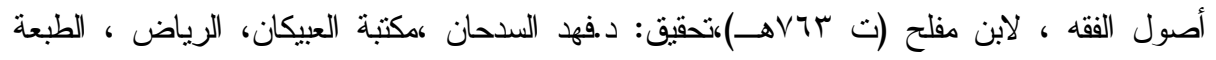

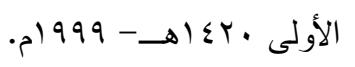

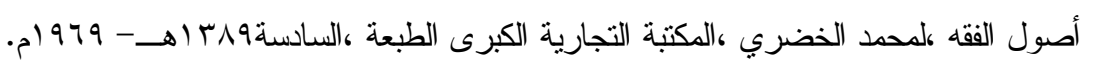

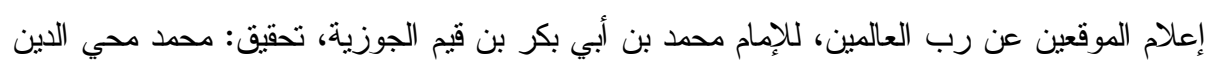

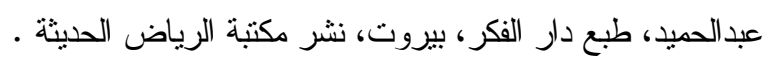

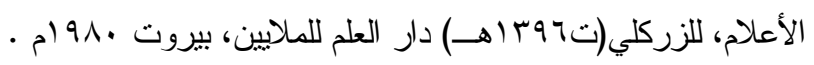

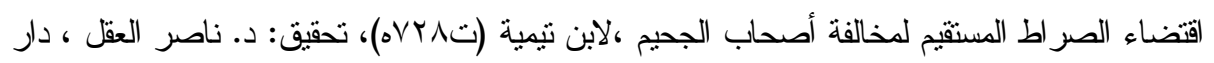

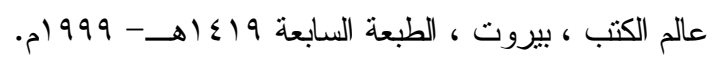

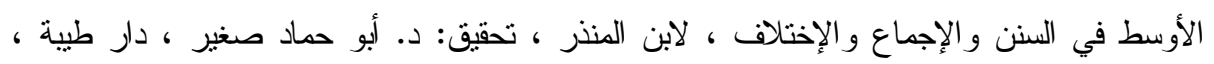

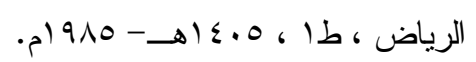
البحر المحيط في أصول الفقه، لبدر الدين الزركثي، تحرير عبدالقادر العاني، مراجعة د. عمر الأثقر ،

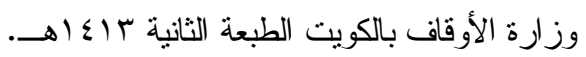

بداية المجتها ونهاية المقتصد ، لأبي الوليد محمد بن رشد القرطبي المالكي ، نعليق: عبدالحليم محمد ،

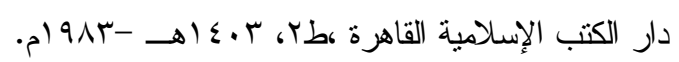

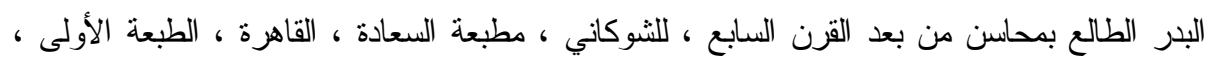
.

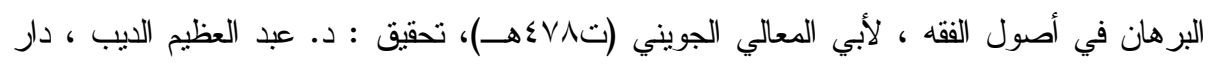

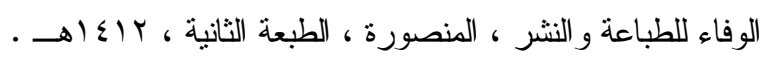

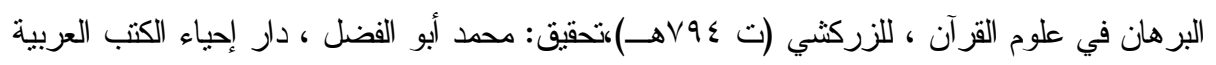

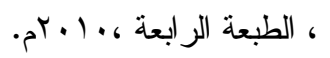
بناء الفروع على الأصول، د. وليد الودعاني، رسالة دكتور اه جامعة الإمام محمد بن سعود الإسلامية ،

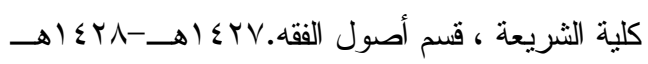

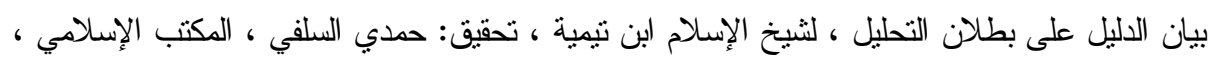

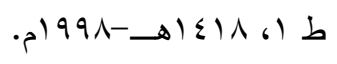

بيان المختصر (ثرح ابن الحاجب) لأبي الثناعمحود الأصفهاني تحقيق: د. محمد البغا،طبع مركز إحياء

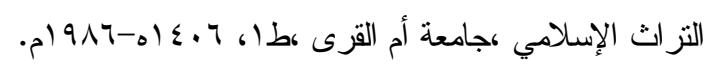


تأصيل بحث المسائل الفقية ،د. خالد السعيدهار الميمان للنشر والتوزيع ، الرياض، الطبعة

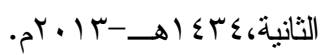
تخريج الفروع على الأصول، للزنجاني (ت 707ه)، تحقيق:د.محمد أديب الصالح، مؤسسة الرسالة

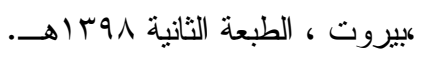
التعريفات ،للثريف الجرجاني(ت7 (1هــ)، دار الكتب العلية ، بيروت ،لبنان ،الطبعة الثالثة ، .019 $9 \lambda-1) \leqslant . \lambda$

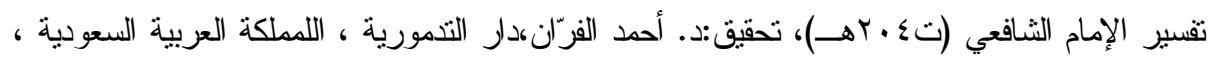

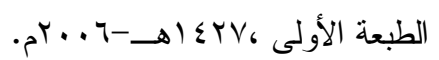
ثقريب الوصول إلى علم الأصول، لأبي القاسم محمد بنجزي ، تحقيق: د. محمد المختار الثنقيطي،

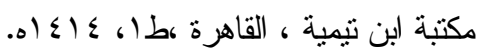

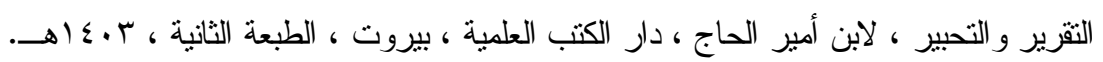

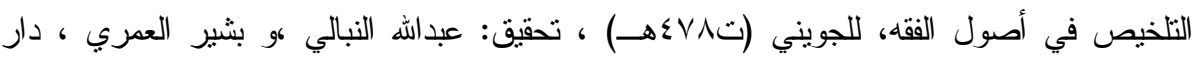

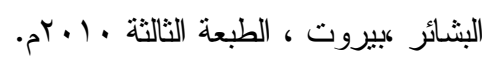

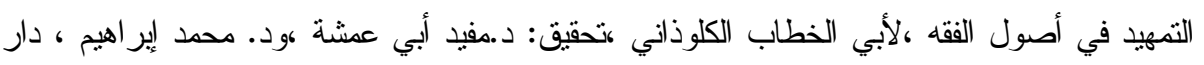

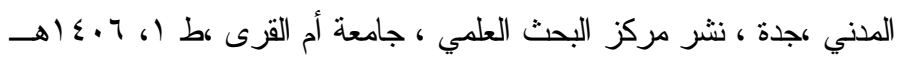

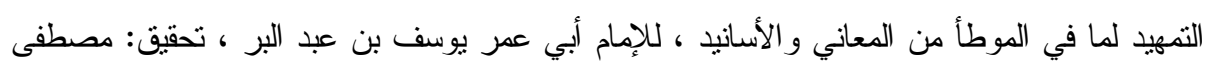

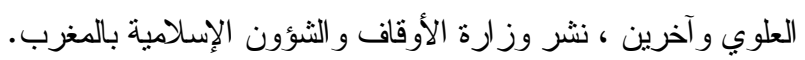

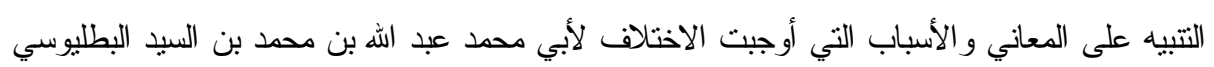

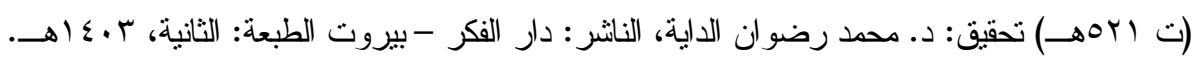

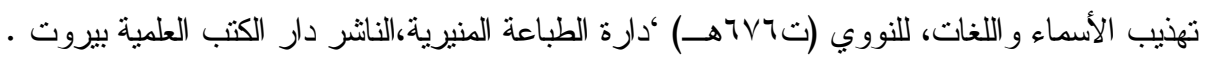

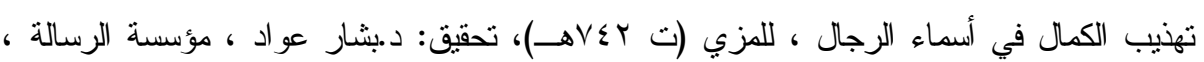

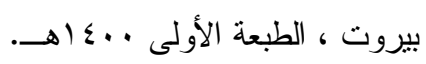
تهنيب اللغة، لمحد بن أحمد الأزهري (ت . لrاهـ) ، تحقيق: محمد عوض، دار إحباء التزراث العربي

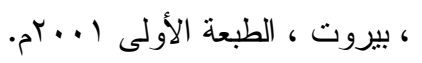

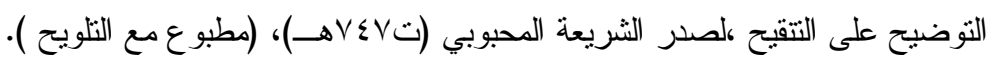
• تيسير التحرير، لأمير با شاه محمد أمين الحنفي، دار الكتب العلمية، بيروت . 
تيسير علم أصول الفقه ،د. عبداله الجليع، مؤسسة الريان للطباعة و النشر و التوزيع، بيروت - لبنان،

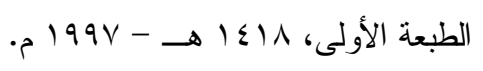

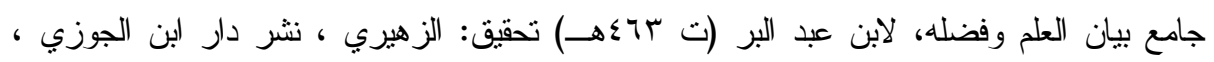

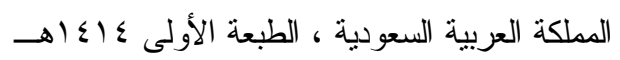

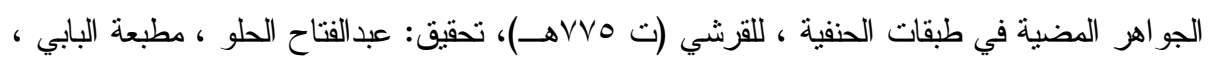
. $19 \vee \Lambda-\rightarrow 1 r 9 \Lambda$

حاثشية ابن عابدين(حانشية رد المحتار على الدر المختار )،للمحق: محمد أمين الثهير ب(ابن

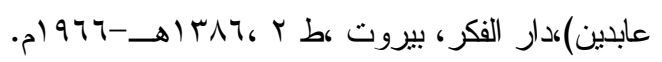

الحاوي الكبير ، للماوردي ، تحقيق: علي معوض وعادل عبدالموجود ، دار الكتب العلمية ، بيروت ،

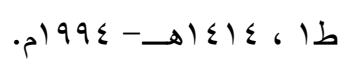

الخلاف: أنو اعه وضو ابطه وكيفية التعامل معههد. حسن العصيمي، دار ابن الجوزي،الطبعة الثانية ، . $1 \leqslant$ ד

الدرر السنية في الأجوبة النجدية ،جمه العلامة عبدالرحمن بن محمد بن قاسم النجدي ،طل ،

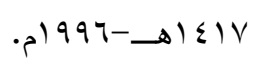

الدرر الكامنة في أعيان المائة الثامنة، لابن حجر العسقلاني (ت أبهـهـ)، مجلس دائرة المعارف العثمانية - حيدر اباد/ الهند. ه الرسالة ، للإمام الثافعي(ت ع • بهـ)، تحقيق: الثنيخ أحمد شاكر، دار الكتب العلية ، بيروت ، لبنان.

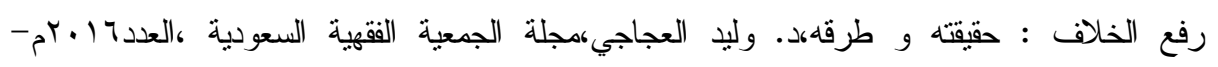

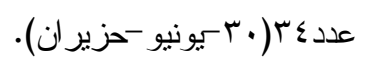
روضة الناظر وجنة المناظر في أصول الفقه، لموفق الدين ابن قدامة، تحقيق: فضيلة د. عبدالكريم

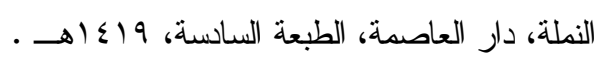

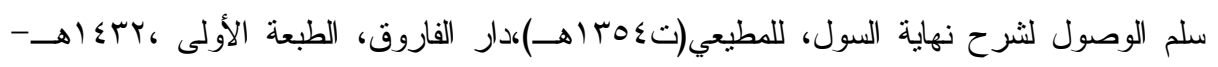
$.0+11$ سنن ابن ماجة ،لإمام أبي عبد الله محمد القزويني كتحقيق: محمد فؤاد عبد الباقي كدار الريان للتزاث ،القاهرة. سنن التزمذي محمد بن عيسى التزمذي، ، تحقيق: أحدد شاكر وآخرون، دار إحياء التزاث العربي، بيروت . 
الأنن الكبرى للبيهقي ، أحمد بن الحسين بن علي كتحقيق: محمد عطا، مكتبة دار الباز ، مكة المكرمة . $998-\longrightarrow$ - إن

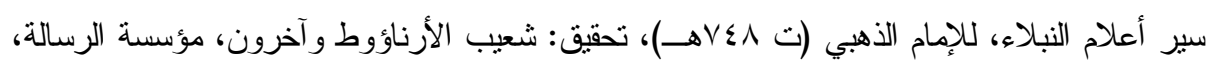

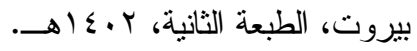

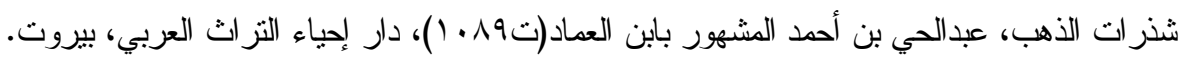

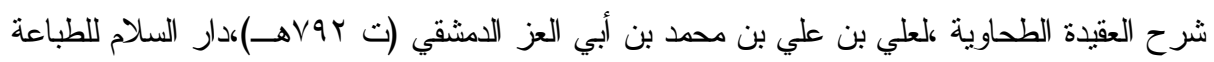

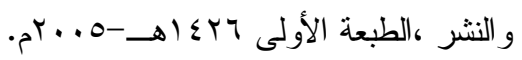

شرح الكوكب المنير، لابن النجار الفتوحي، تحقيق: د. محمد الزحيلي ود. نزيه حماد، مركز البحث العلمي بجامعة أم القرى بمكة المكرمة.

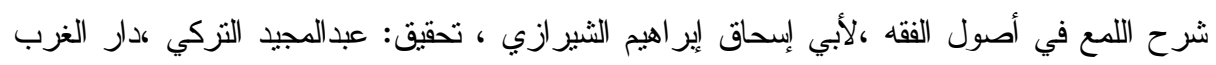

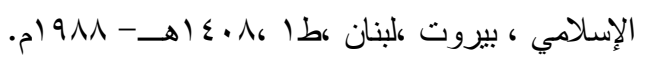

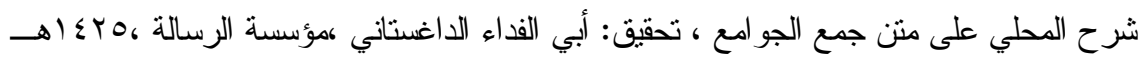

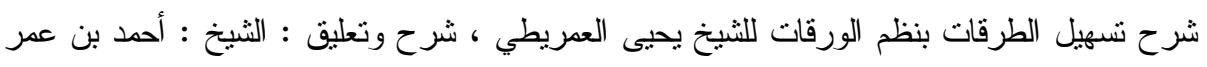
• الحازمي شرح تتقيح الفصول في اختصار المحصول في الأصول، للإمام القر افي، دار الفكر، القاهرة، الطبعة

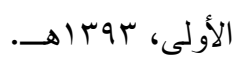

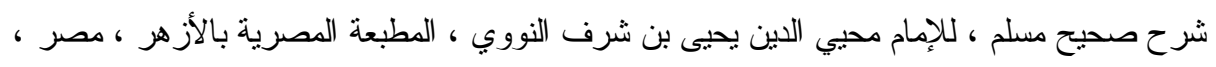

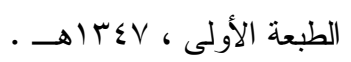
شرح مختصر الروضة، للطوفي، نحقيق، أدد عبداله التركي، مؤسسة الرسالة، الطبعة الأولى، . () صحيح البخاري، للإمام محمد بن إبماعيل البخاري، مطبوع مع فتح الباري، ترقيم فو ائد عبد الباقي،

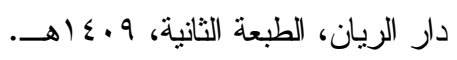
صحيح الجامع وزيادته، للعلامة الألباني، إثثراف زهير الثشاويش، المكتب الإنسامي، بيروت، الطبعة الثانية، 7 • أهـ. صحيح مسلم، للإمام مسلم بن الحجاج النيسابوري، تحقيق: فو ائد عبد الباقي، دار إحياء الكتب العلية،

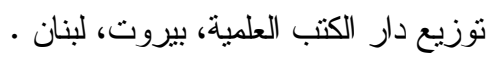


الضوابط الأصولية دراسة تأصيلية نطبيقية ،د. عبدالرحمن الحطاب ،مجلة الجامعة الإسلامية ،العدد

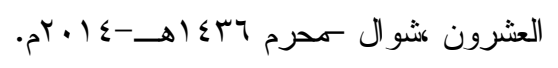

الضوابط الأصولية في الاجتهاد في السياسة الثرعية ،د. عبدالكريم الثقاقي، دار الكثب العلية ، الطبعة

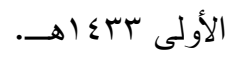

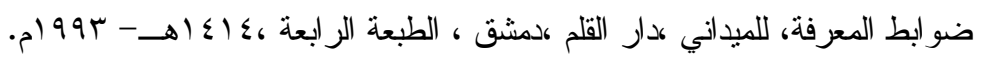

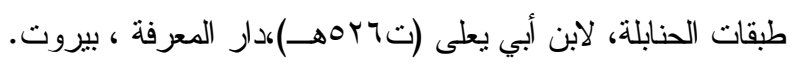

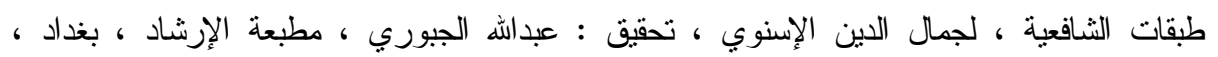
. ه

طبقات الثنافعية الكبرى، لتاج الدين عبدالوهاب السبكي(ت (VVهـ) ، تحقيق : د. عبدالفتاح الحلو ،ود.

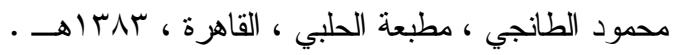

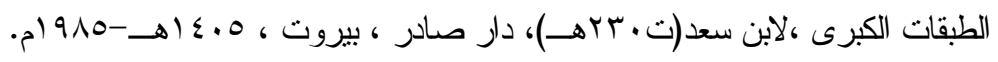

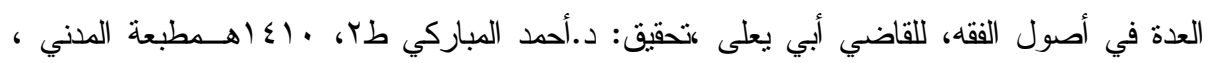
القاهرة.

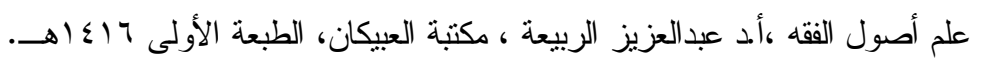

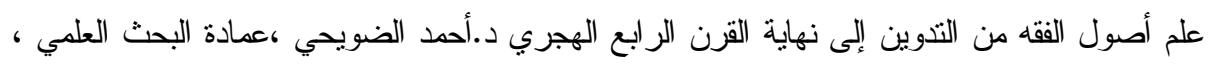

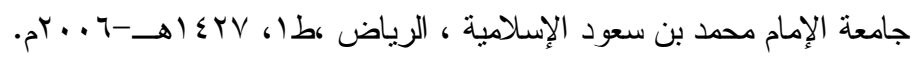

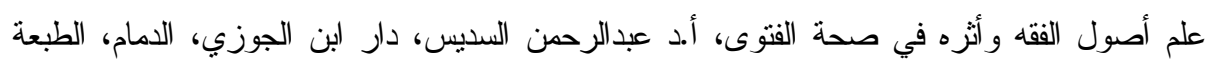

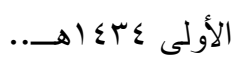

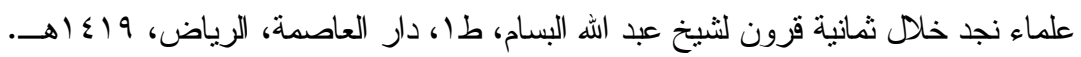

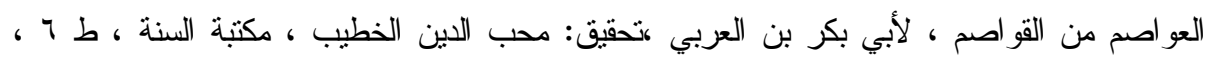

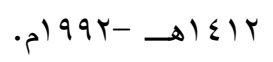

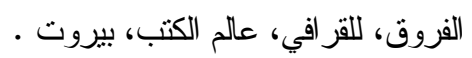

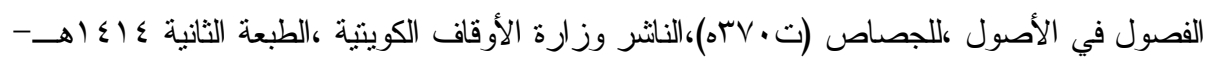
$.0199 \varepsilon$ هقه الخلاف بين المسلمين دعوة إلى علاقة أفضل بين الإتجاهات الإنسلامية المعاصرة،د. ياسر

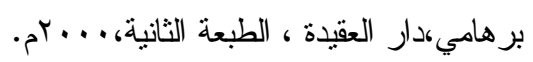




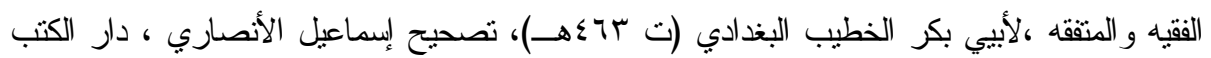

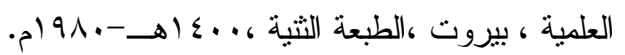

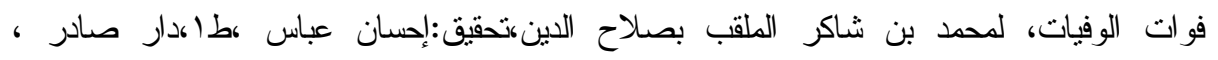

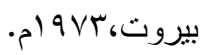

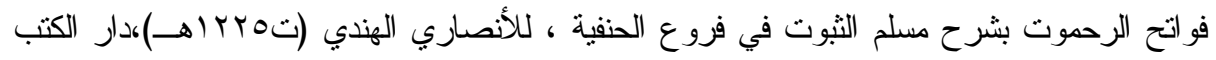
العلمية ، بيروت . الفو اكه الدواني بشرح الثيخ أحمد النفر اوي على رسالة أبي محد القيرو اني ، مطبعة مصطفى البابي مان

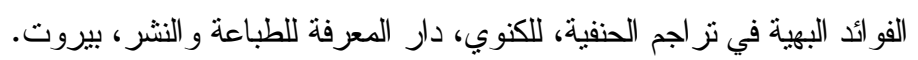

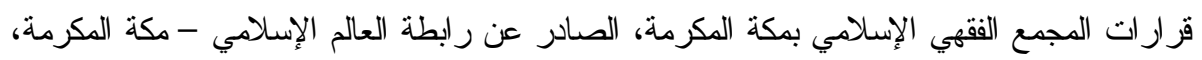

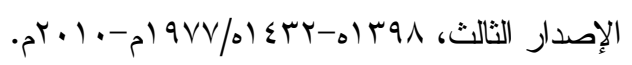

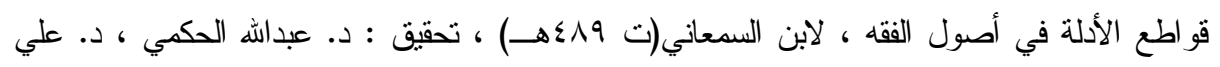

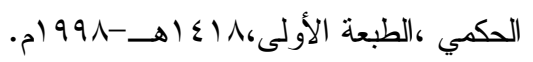
قو اعد أصول الفقه وتطبيقاتها ، د. صفوان داوودي، دار العاصمة ، الرياض ، الطبعة الأولى ، .

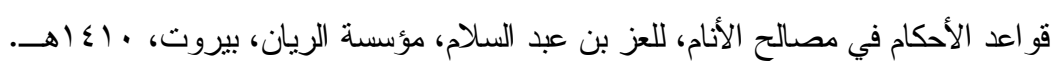

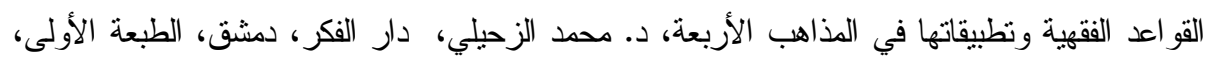
. $\rightarrow$ I Y V

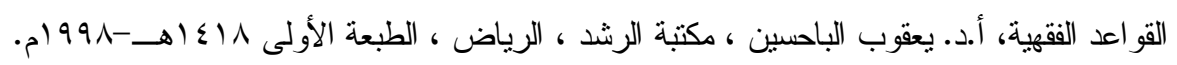

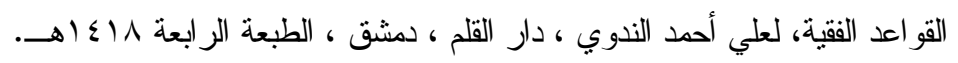

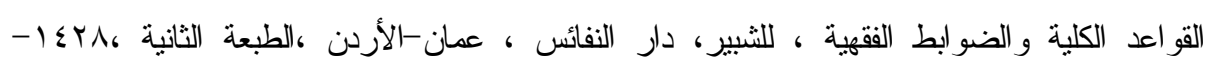
. كثف الأسر ار عن أصول فخر الإسلام البزدوي، لعبد العزيز البخاري، تحقيق ك محد البغدادي، دار

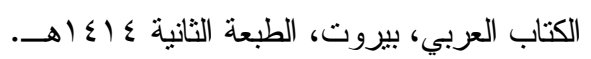

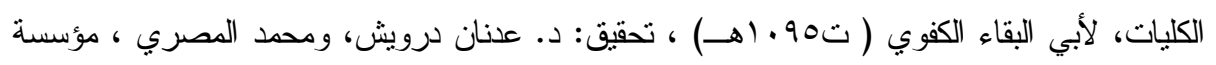

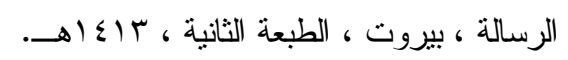

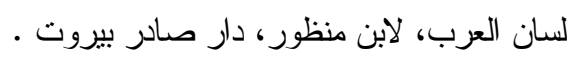

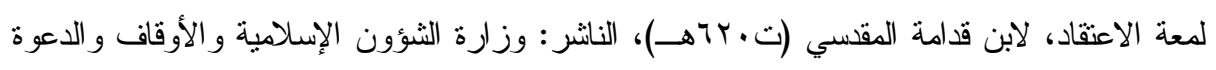

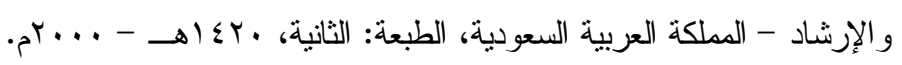


مبادئ علم القو اعد الأصولية، د. إنساعيل عبد عباس ،الناثر الدرسة الدكية.

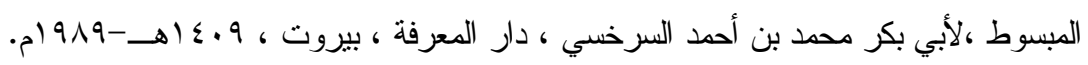

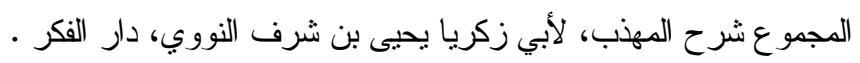

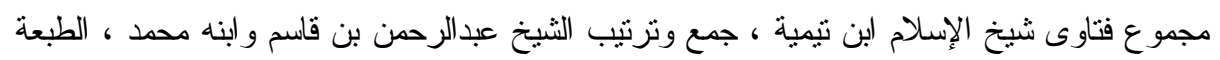

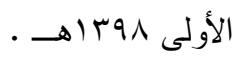
المحصول في علم الأصول، للرازي، تحقيق: د.طه العلواني، مطبعة جامعة الإمام محمد بن سعود

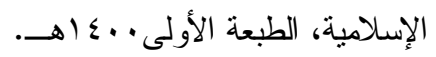
المحلى ، للإمام علي بن حزم الظاهري ، تحقيق: لجنة إحياء التزاث العربي ، دار الآفاق الجديدة ، بيروت .

مختصر الصواعق المرسلة ،لابن القيم(ت (لههـ)، اختصره الثنيخ: محدد الموصلي،صحيح:زكريا على يوسف همطبعة الإمام ،مصر. مختصر منتهى السؤل و الأمل في علمي الأصول و الجدل ، لابن الحاجب(ت بـ آهـ) ، تحقيق: د.نزيه

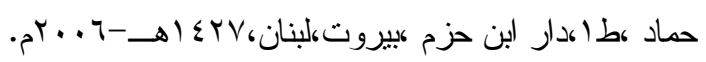
مذكرة في أصول الفقه، للعلامة محمد الأمين الثنقيطي، المكتبة السلفية، المدينة المنورة.

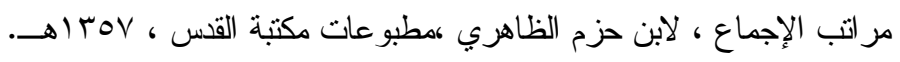

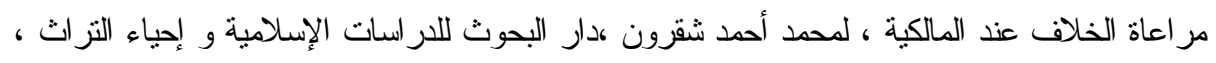

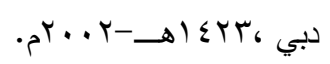
ا المستصفى في علم أصول الفقه، للإمام الغزالي ، ط أهار الكتب العلمية كبيروت.

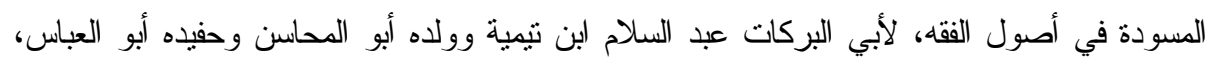

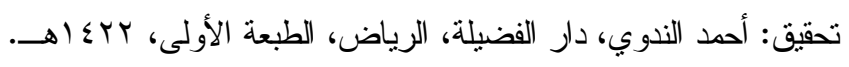

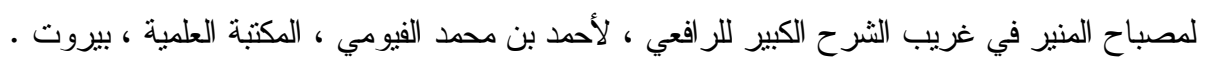

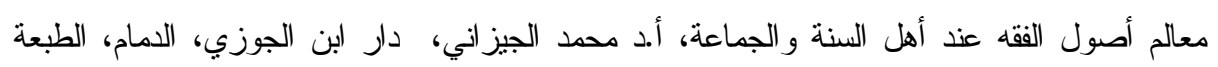

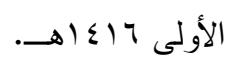
المعتمد في أصول الفقه، لأبي الحسين محمد بن علي البصري ،تقليم وضبط: الثيخ خليل الميس،دار الكتب العلمية كبيروت ، لبنان. معجم لغة الفقهاء، لمحمد رواس قلعجي -حامد صادق قنيبي ،دار النفائس ،الطبعة الثانية م مــأهـ$\left.\Lambda_{p}\right) 9 \Lambda \Lambda$ معجم مصطلحات أصول الفقه، لمحمد سانو، دار الفكر المعاصر للطباعة و النشر، ... بام.

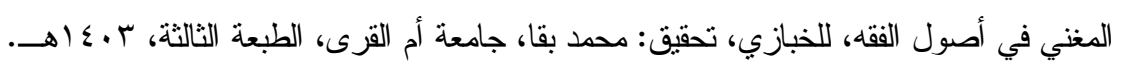


المفردات في غريب القر آن ، لأبي القاسم محمد المعروف ب(الر اغب الأصفهاني ت ب.0هـ، تحقيق: محمد كيلاني ، دار المعرفة ، بيروت.

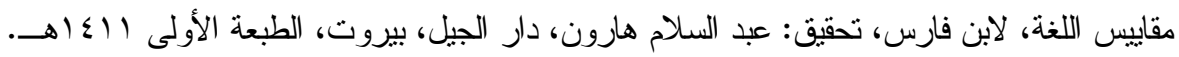

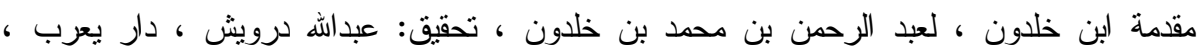

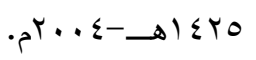

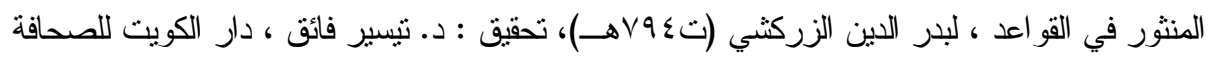

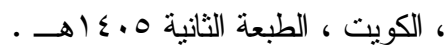

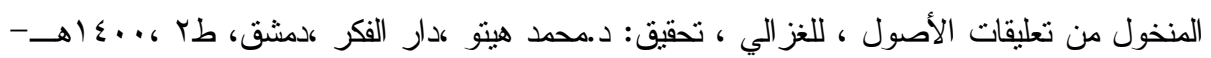
. 191 . منهج البحث في الفقه الإنلامي ،أ.د عبداللوهاب أبو سليمان ،دار ابن حزم.

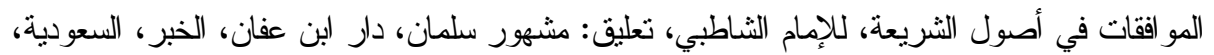

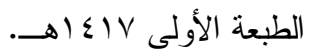
مو اهب الجليل في شرح مختصر خليل ، لثمس الدين للحطاب ، دار الفكر ،ط ب، باء اهــــ .01994

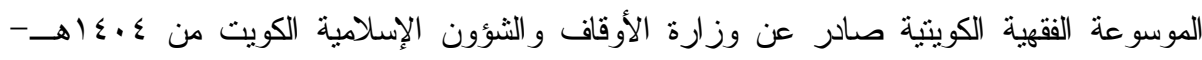
. $\rightarrow$ I $Y Y$

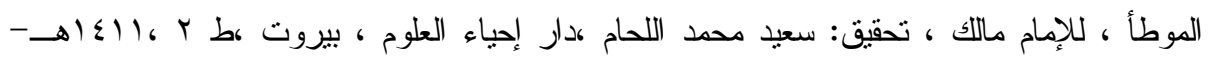
.0199 . نفائس الأصول في شرح الدحصول ، للإمام القر افي ، تحقيق : عادل أحمد عبد الموجود ، وعلي

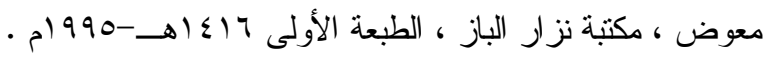

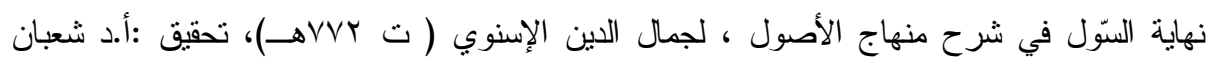

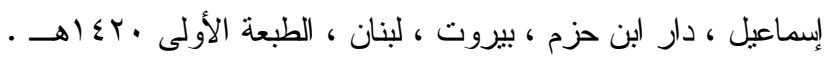

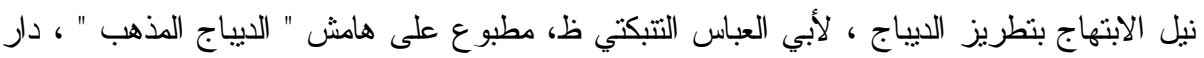
الكتب العلمية ، بيروت .

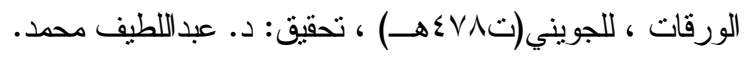

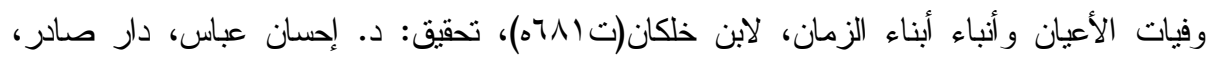


